\title{
Analysis of streamflow response to land use and land cover changes using satellite data and hydrological modelling: case study of Dinder and Rahad tributaries of the Blue Nile (Ethiopia-Sudan)
}

\author{
Khalid Hassaballah $^{1,2,3}$, Yasir Mohamed ${ }^{1,2,3}$, Stefan Uhlenbrook ${ }^{1,2,4}$, and Khalid Biro ${ }^{3}$ \\ ${ }^{1}$ IHE-Delft Institute for Water Education, P.O. Box 3015, 2601DA Delft, the Netherlands \\ ${ }^{2}$ Delft University of Technology, P.O. Box 5048, 2600 GA Delft, the Netherlands \\ ${ }^{3}$ The Hydraulics Research Center, P.O. Box 318, Wad Medani, Sudan \\ ${ }^{4}$ UNESCO, Villa La Colombella - 06134 Colombella Alta, Perugia, Italy \\ Correspondence to: Khalid Hassaballah (k.hassaballah@yahoo.com)
}

Received: 7 March 2017 - Discussion started: 20 March 2017

Revised: 14 August 2017 - Accepted: 31 August 2017 - Published: 17 October 2017

\begin{abstract}
Understanding the land use and land cover changes (LULCCs) and their implication on surface hydrology of the Dinder and Rahad basins (D\&R, approximately $77504 \mathrm{~km}^{2}$ ) is vital for the management and utilization of water resources in the basins. Although there are many studies on LULCC in the Blue Nile Basin, specific studies on LULCC in the D\&R are still missing. Hence, its impact on streamflow is unknown. The objective of this paper is to understand the LULCC in the Dinder and Rahad and its implications on streamflow response using satellite data and hydrological modelling. The hydrological model has been derived by different sets of land use and land cover maps from 1972, 1986, 1998 and 2011. Catchment topography, land cover and soil maps are derived from satellite images and serve to estimate model parameters. Results of LULCC detection between 1972 and 2011 indicate a significant decrease in woodland and an increase in cropland. Woodland decreased from 42 to $14 \%$ and from 35 to $14 \%$ for Dinder and Rahad, respectively. Cropland increased from 14 to $47 \%$ and from 18 to $68 \%$ in Dinder and Rahad, respectively. The model results indicate that streamflow is affected by LULCC in both the Dinder and the Rahad rivers. The effect of LULCC on streamflow is significant during 1986 and 2011. This could be attributed to the severe drought during the mid-1980s and the recent large expansion in cropland.
\end{abstract}

\section{Introduction}

Streamflow is an important hydrological variable needed for water resource planning and management and for ecosystem conservations. The rainfall runoff process over the upper Dinder and Rahad basins (D\&R) is complex and non-linear and exhibits temporal and spatial variability (Hassaballah et al., 2016). To manage water resources effectively at a local level, decision makers need to understand how human activities and climate change may impact local streamflow. Therefore, it is necessary to understand the hydrological processes in the runoff-generated catchments and the possible interlinkages of land use and land cover changes with catchment runoff. For this reason, we used satellite data and hydrological modelling to analyse the land use and land cover changes (LULCCs) and their impacts on streamflow response in the D\&R.

The D\&R generate around $7 \%$ of the Blue Nile Basin's annual flow. The Rahad River supplies water to the Rahad Irrigation Scheme (100000 ha), while the Dinder River supplies water to the diverse ecosystem of the Dinder National Park (DNP). The DNP (10 $\left.291 \mathrm{~km}^{2}\right)$ is a vital ecological area in the arid and semi-arid Sudanese-Saharan region.

The Dinder and Rahad rivers have experienced significant changes in floodplain hydrology in recent years, which some claim is caused by land use and land cover changes in the upstream catchment. The floodplain hydrology defines the seasonal wetlands ("mayas") which are the only source of water in the DNP during the dry season (8 months). The hydrology 
of the mayas has large implications on the ecosystem of the DNP. A detailed description of the mayas wetlands can be found in Hassaballah et al. (2016).

LULCC was identified as a key research priority with multi-directional impacts on both human and natural systems (Turner II et al., 2007). Many studies highlighted the impacts of LULCC on hydrology (DeFries and Eshleman, 2004; Uhlenbrook, 2007), on ecosystem services (DeFries and Bounoua, 2004; Metzger et al., 2006; Polasky et al., 2011) and on biodiversity (Hansen et al., 2004; Hemmavanh et al., 2010).

LULCC is a widespread observable phenomenon in the Ethiopian highlands, as shown by Zeleke and Hurni (2001), Bewket and Sterk (2005), Hurni et al. (2005) and Teferi et al. (2013). These studies have pointed out different types and rates of LULCC in different parts of the Ethiopian highlands over different time periods and reported that the expansion of croplands associated with a decrease in woodlands has been the general form of transitions.

Recently, Gumindoga et al. (2014) assessed the effect of land cover changes on streamflow in the upper Gilgel Abbay river basin in northwestern Ethiopia. Their results showed significant land cover changes where cropland has changed from $30 \%$ of the catchment in 1973 to $40 \%$ in 1986 and $62 \%$ in 2001 . The study attributed these changes to the increase in population, which increased the demands for agricultural land. The study has also shown that farmers in the area are commonly clearing forests to create croplands, and the resulting effect was the decrease in forested land from $52 \%$ in 1973 to $33 \%$ in 1986 and $17 \%$ in 2001. Since the Upper Blue Nile Basin is neighbouring the D\&R, one may expect some similarities of catchment characteristics, though differences cannot be excluded. These transitions have contributed to the high rate of soil erosion and land degradation in the Ethiopian plateau (Bewket and Teferi, 2009). Understanding the impacts of LULCC on hydrology and incorporating this understanding into the emerging focus on LULCC science are the most important needs for the future (Turner et al., 2003).

Many models have been developed to simulate impacts of LULCC on streamflow. These can be categorized as an empirical black-box, conceptual, and physically based distributed models. Each type of these three models has its own advantages and limitations. Several situations in practice demand the use of simple tools such as the linear system models or black-box models. Nevertheless, these simpler models usually fail to mimic the non-linear dynamics, which are essential in the rainfall-runoff transformation process. Therefore, the development of a dynamic modelling language within a GIS framework such as PCRaster is a further important stage that allows complex models, such as the WFlow rainfall-runoff model, to be implemented, making use of globally available spatial datasets. The PCRaster programming language is an environmental modelling language to build dynamic spatial environmental models (Bates and
De Roo, 2000; Karssenberg, 2002; Uhlenbrook et al., 2004). Such spatially distributed models also have the potential to help in answering questions of policymakers about the impact of spatial changes (e.g. impacts of LULCC on streamflow dynamic). It has been shown that a variety of probable LULCC impacts on hydrologic processes in the D\&R are likely to happen. Therefore, the objective of this study is to understand the LULCC in the D\&R and its impacts on streamflow response using satellite data, GIS and remote sensing, as well as hydrological modelling. The WFlow distributed hydrological model (Schellekens, 2011) is used to simulate the processes. In addition, understanding the level to which the streamflow has altered is critical for developing an effective management plan for ecosystem restoration and conservation. Thus, the indicators of hydrological alteration (IHA) approach proposed by Richter et al. (1996) was then applied to analyse the streamflow characteristics likely to affect the ecological processes in the $\mathrm{D} \& \mathrm{R}$, including flow magnitude, timing and rate of change of flow.

\section{Study area}

The Dinder and the Rahad are the lower sub-basins of the Blue Nile River basin located between longitude $33^{\circ} 30$ and $37^{\circ} 30^{\prime} \mathrm{E}$ and latitude $11^{\circ} 00$ and $15^{\circ} 00^{\prime} \mathrm{N}$ (Fig. 1). The Blue Nile Basin collects flows of eight major tributaries in Ethiopia besides the two main tributaries in Sudan: the Dinder and the Rahad rivers. Both tributaries derive their water from the runoff of the Ethiopian highlands approximately $30 \mathrm{~km}$ west of Lake Tana (Hurst et al., 1959). Their catchments areas are about 34964 and $42540 \mathrm{~km}^{2}$ for the Dinder and the Rahad, respectively, giving a total area of about $77504 \mathrm{~km}^{2}$. The catchment has varied topography with elevation ranges between about $384 \mathrm{~m}$ at the catchment outlet and up to $2731 \mathrm{~m}$ at the Ethiopian plateau. The D\&R have a complex hydrology, with varying climate, topography, soil, vegetation and geology (Hassaballah et al., 2016). The annual average flow is about $2.797 \times 10^{9}$ and $1.102 \times$ $10^{9} \mathrm{~m}^{3}$ year $^{-1}$ for the Dinder and the Rahad, respectively.

\section{Data and methods}

Limited data are available for simulating the hydrology of the D\&R. To fill this data gap, use has been made of globally available free datasets. The datasets which have been used to run the WFlow model are divided into two datasets: static data and dynamic data.

\subsection{Input data}

\subsubsection{Static data}

The static data contain maps that do not change over time. They include maps of the catchment delineation, digital 


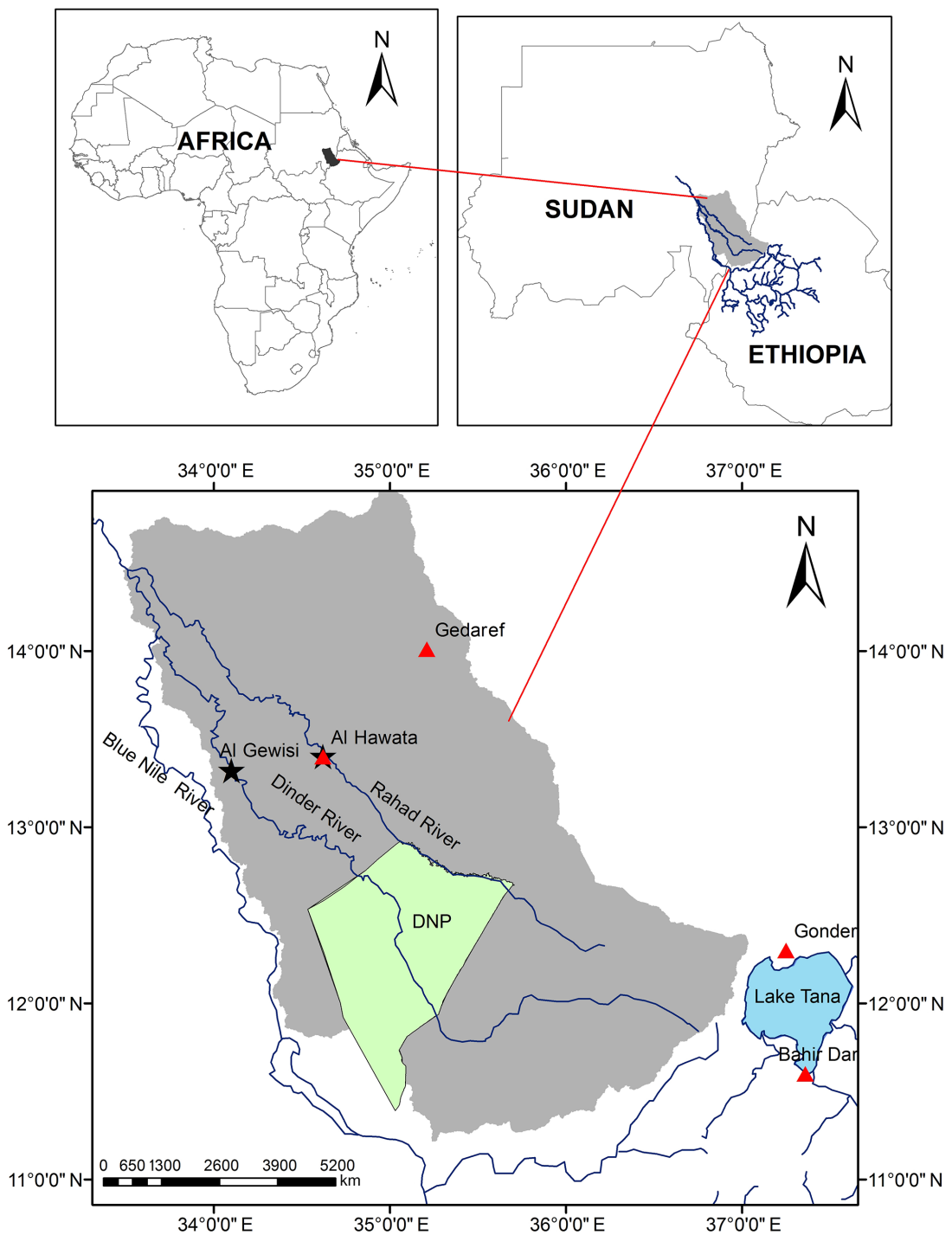

Figure 1. Location map of the Dinder and Rahad basins and the DNP. The two black stars show the locations of the hydrological stations (Al Gewisi and Al Hawata), and the red triangles show the locations of the rain gauges.

elevation maps (DEMs), gauging points, land use, local drainage direction (LDD), outlets and rivers. These maps were created with pre-prepared processes of the WFlow hydrologic model.

The catchment boundary has been delineated based on a $90 \mathrm{~m} \times 90 \mathrm{~m}$ DEM of the NASA Shuttle Radar Topographic Mission (SRTM) obtained from the Consortium for Spatial Information (CGIAR_CSI) website (http://srtm.csi.cgiar. org).

Multi-temporal Landsat data for the years 1972, 1986, 1998 and 2011 were obtained free of charge from the internet site of the United States Geological Survey (USGS) (source: http://glovis.usgs.gov/). All images were geometrically corrected into the Universal Transverse Mercator (UTM) coordinate system (Zone-36N).
The soil map was obtained free of charge from the Food and Agriculture Organization (FAO) Harmonized World Soil Database (HWSD). The original catchment boundary layer provided 44 soil mapping unit (SMU) classes. These classes have been reclassified into 8 dominant soil group (DSG) categories, based on the DSG of each soil mapping unit code. This was necessary to reduce the model complexity. The WFlow soil model requires estimates of 8 parameters per soil type, which means 352 parameters if it is for 44 soil types. Therefore, reclassification of the soil map into 8 dominant soil groups reduces the number of estimated parameters to 64 . The categories are vertisols $(71 \%)$, luvisols $(9 \%)$, nitisols $(8 \%)$, leptosols $(5 \%)$, cambisols $(4 \%)$, alisols $(2 \%)$ and fluvisols $(1 \%)$. The map was then projected to WGS-84UTM-zone-36N and resampled to a horizontal resolution of $500 \mathrm{~m}$. 


\subsubsection{Satellite-based rainfall and evapotranspiration data}

The dynamic data contain maps that change over time. It includes daily maps of the precipitation and evapotranspiration. These maps were created with a pre-preparation step1 and step2 of WFlow model. In this study, three open-access satellite-based rainfall estimate (SBRE) products were compared based on their runoff performance at Al Gewisi and Al Hawata stations the outlets of the Dinder and Rahad basins, respectively. The best product was then used to run the WFlow model using different land use and land cover (LULC) maps. The SBRE and the evapotranspiration products used in this study are rainfall estimates (RFE 2.0), potential evapotranspiration (PET), Tropical Rainfall Measuring Mission (TRMM) and Climate Hazards Group Infrared Precipitation with Stations (CHIRPS).

The RFE 2.0 and the PET data were obtained from the Famine Early Warning System Network (FEWS NET). The horizontal resolution is $0.1^{\circ}(11.0 \mathrm{~km})$ for the RFE and $1.0^{\circ}$ $(110 \mathrm{~km})$ for PET. These data are available on a daily basis from 2001 to near real-time period of record. More detail can be found at http://earlywarning.usgs.gov/adds/downloads/.

The TRMM is a joint space mission between NASA and the Japan Aerospace Exploration Agency (JAXA), launched in 1997. The TRMM satellite rainfall measuring instruments include the Precipitation Radar (PR), TRMM Microwave Image (TMI), a nine-channel passive microwave radiometer, a visible and infrared scanner (VIRS) and a five-channel visible-infrared radiometer (Huffman and Bolvin, 2013). In this study, we have used TRMM 3B42v7 which has a spatial resolution of $0.25^{\circ}$ and a temporal resolution of $3 \mathrm{~h}$. More information can be found at https://trmm.gsfc.nasa.gov/.

The CHIRPS data were developed by the Climate Hazards Group (CHG) and scientists at the US Geological Survey Earth Resources Observation and Science Center. This product is a new quasi-global precipitation with daily to seasonal timescales, a $0.05^{\circ}$ resolution and a period of record from 1981 to near-real time. The CHIRPS uses the monthly Climate Hazards Precipitation Climatology (CHPClim), the infrared (IR) sensors from the Group on Earth Observations (GEO) satellites, the TRMM 3B42 product and the ground precipitation observations. More information about CHIRPS data can be found in Funk et al. (2014). A summary of all precipitation and evapotranspiration satellite products was provided in Table 1. All maps were projected into WGS-84UTM-zone $36 \mathrm{~N}$ (metres), clipped to catchment extent, and then resampled to a resolution of $500 \mathrm{~m}$.

\subsubsection{Observed hydrological streamflow}

Daily streamflow data at Al Gewisi station on the Dinder River and at Al Hawata station on the Rahad River for the period 2001-2012 were obtained from the Ministry of Water Resources, Irrigation and Electricity Sudan. These data are mainly used for calibration and validation of the WFlow hydrological model.

\subsection{LULC classification and change detection}

LULC images were selected in the same season to minimize the influence of seasonal variations on the classification result. All acquired images had less than $10 \%$ cloud cover. However, in order to cover the entire study area, more than eight scenes of the satellite data were processed (Table 2). Subsequently, all images were mosaicked and resampled to a pixel size of $30 \mathrm{~m} \times 30 \mathrm{~m}$. The classification results of the historical images 1972, 1986 and 1998 were validated through visual interpretation of the unclassified satellite images and supported by in-depth interviews with local elders. The classification of the 2011 image was validated by ground survey during a field visits throughout the study area during the period between 2011 and 2013, assuming no significant change during this period. A Global Positioning System (GPS) device was used to obtain exact location point data for each LULC class included in the classification scheme and for the creation of training sites and for signature generations as well. Moreover, field notes, site descriptions and terrestrial photographs were taken to relate the site location to scene features. A total of 120 training areas were selected based on image interpretation keys, established during the field survey and from interviews with the local people. This later step was used as a crosscheck validation for the visual interpretation performed to the historical images. A supervised maximum likelihood classification (MLC) technique was independently employed to the individual images. MLC is the most common supervised classification method used with remote sensing image data (Ellis et al., 2010; Pradhan and Suleiman, 2009). The derivation of MLC is generally acceptable for remote sensing applications and is used widely (Richards et al., 2006).

The accuracy assessment of the classified images was based on the visual interpretation of the unclassified satellite images (Biro et al., 2013). However, the visual interpretation was conducted by an independent analyst not involved in the classification. The stratified random sampling design, where the number of points was stratified to the LULC types, was adopted in order to reduce bias (Mundia and Aniya, 2006). Accordingly, error matrices as cross-tabulations of the classified data vs. the reference data were used to evaluate the classification accuracy. The overall accuracy, the user's and producer's accuracies, and the Kappa statistic values were then derived from the error matrices.

Multi-date post-classification comparison (PCC) change detection method described by Yuan et al. (2005) was used to determine the LULCC in three intervals: 1972-1986, 19861998 and 1998-2011. PCC is a quantitative technique that involves an independent classification of separate images from different dates for the same geographic location, followed by a comparison of the corresponding pixels (thematic la- 
Table 1. Summary of the different precipitation and evapotranspiration satellite products.

\begin{tabular}{lllllll}
\hline Product & Developer & $\begin{array}{l}\text { Spatial } \\
\text { resolution }\end{array}$ & Covering area & $\begin{array}{l}\text { Temporal } \\
\text { resolution }\end{array}$ & Time span & $\begin{array}{l}\text { Ground } \\
\text { measurement }\end{array}$ \\
\hline TRMM 3B42v7 & NASA, JAXA & $0.25^{\circ}$ & $0^{\circ} \mathrm{E}-360^{\circ} \mathrm{E} / 50^{\circ} \mathrm{N}-50^{\circ} \mathrm{S}$ & 3 hourly & Jan 1998-present & Yes \\
RFE 2.0 & NOAA (CPC) & $0.1^{\circ}$ & $20^{\circ} \mathrm{E}-55^{\circ} \mathrm{E} / 40^{\circ} \mathrm{N}-40^{\circ} \mathrm{S}$ & 6 hourly & Jan 2001-present & Yes \\
CHIRPS v2.0 & CHG & $0.05^{\circ}$ & $0^{\circ} \mathrm{E}-360^{\circ} \mathrm{E} / 50^{\circ} \mathrm{N}-50^{\circ} \mathrm{S}$ & Daily & Jan 1981-present & Yes \\
PET & NOAA (CPC) & $1.0^{\circ}$ & $20^{\circ} \mathrm{E}-55^{\circ} \mathrm{E} / 40^{\circ} \mathrm{N}-40^{\circ} \mathrm{S}$ & 6 hourly & Jan 2001-present & Yes \\
\hline
\end{tabular}

bels) in order to identify and quantify areas of change (Al Fugara et al., 2009; Jensen, 2005). It is the most commonly used method of LULCC detection mapping (Kamusoko and Aniya, 2009).

\subsection{Description of the WFlow hydrological model}

In order to assess the impacts of LULCC on the streamflow dynamic, the WFlow distributed hydrological model (Schellekens, 2011) is forced using SBRE. The WFlow is a state-of-the-art open-source distributed catchment model. The model is part of the Deltares OpenStreams project (http://www.openstreams.nl). The model is derived from the CQFLOW model (Köhler et al., 2006). It is a hydrological model platform that includes two models: the WFlow_sbm model described by Vertessy and Elsenbeer (1999), derived from the TIOPG_SBM soil concept, and the WFlow_hbv model (distributed version of the HBV model). The model directly appeals to the need within the hydrological and geomorphologic sciences community to effectively use spatial datasets, e.g. digital elevation models, land use maps, dynamic satellite data for rapid and adequate modelling of river basins with limited data availability. The model is programmed in PCRaster GIS dynamic language (Deursen, 1995).

In this study, the WFlow_sbm PCRaster-based distributed hydrological model, which makes use of the Gash and the TOPOG_SBM models, was used. The model requires less calibration and maximizes the use of available spatial data that make it a suitable model for this study. Step one of WFlow model was to delineate the river network and the gauging points based on the DEM. Next, a land use and soil maps were added to the model, and parameters were estimated based on physical characteristics of the soil and land use type. The rainfall interception was calculated using the Gash model (Gash, 1979, 1995), while hydrologic processes that cause a runoff or overland flow were calculated using the TOPOG_SBM model. The WFlow uses potential evapotranspiration as input data and derives the actual evaporation based on soil water content and vegetation cover type. The analytical model of rainfall interception in the WFlow is based on Rutter's numerical model (Gash, 1979; Gash et al., 1995). The surface runoff is modelled using a kinematic wave routine. Combination of the total rainfall and evaporation under saturated-canopy conditions is done for each rainfall storm to determine average values of precipitation and evaporation from the wet canopy. In case the soil surface is partially saturated, the rainfall that falls on the saturated area is directly added to the surface runoff component. The soil is represented by a simple bucket model that assumes an exponential decay of the saturated conductivity with depth. Lateral subsurface flow is simulated using the Darcy equation. Soil depth is identified for different land use types and consequently scaled using the topographic wetness index. Different parameters are assigned to each land cover type. These parameters include rooting depth, leaf area index (LAI), ratio of evaporation from wet canopy to average rainfall $\left(E_{\mathrm{w}} / R\right)$, albedo, canopy gap fraction and maximum canopy storage. All model parameters are linked to the Wflow model through lookup tables. The lookup tables are used by the model to create input parameter maps. Each table consists of four columns. The first column is used to identify the land use class, the second column indicates the sub catchment, the third column represents the soil type and the last column lists the assigned values based on the first three columns. The parameters are linked to land use, soil type or sub-catchment through lookup tables. A description of the Wflow model parameters is presented in Appendix B and the calibrated values for each parameter are presented in Appendix C. The WFlow_sbm interception and soil model's equations are presented in Appendix A. Further details of the Wflow model are also given at https://media.readthedocs.org/pdf/wflow/latest/wflow.pdf.

The model is fully distributed, which means that it makes the calculations for every grid cell of the basin. Each cell $(500 \mathrm{~m} \times 500 \mathrm{~m})$ is seen as a bucket with a total depth divided into saturated and unsaturated stores (Fig. 2). The streamflow model results were then analysed using the IHA approach described by Richter et al. (1996).

\subsubsection{Model calibration and validation}

As with all hydrological models, calibration of the Dinder and Rahad hydrological model is needed for optimal performance. Since the hydrological data available for calibration start from 2001, the nearest land use (land use data from 1998) was used in the calibration. The calibration procedure performed in two steps based on, first, initial values of all parameters were estimated based on the land use and the soil 
Table 2. Description of satellite images used.

\begin{tabular}{llrll}
\hline Acquisition date & Satellite & $\begin{array}{r}\text { Number of } \\
\text { scenes }\end{array}$ & Spectral bands & $\begin{array}{l}\text { Spatial } \\
\text { resolution }\end{array}$ \\
\hline 4 Nov and 11 Dec 1972 & Landsat MSS & 9 & $1-4$ bands & $60 \mathrm{~m}$ \\
12 Nov and 26 Nov 1986 & Landsat TM & 9 & $1-6$ bands & $30 \mathrm{~m}$ \\
27 Nov and 13 Dec 1998 & Landsat TM & 8 & $1-6$ bands & $30 \mathrm{~m}$ \\
7 Nov and 10 Dec 2011 & Landsat TM & 8 & $1-6$ bands & $30 \mathrm{~m}$ \\
\hline
\end{tabular}

MSS: multispectral scanner; TM: thematic mapper

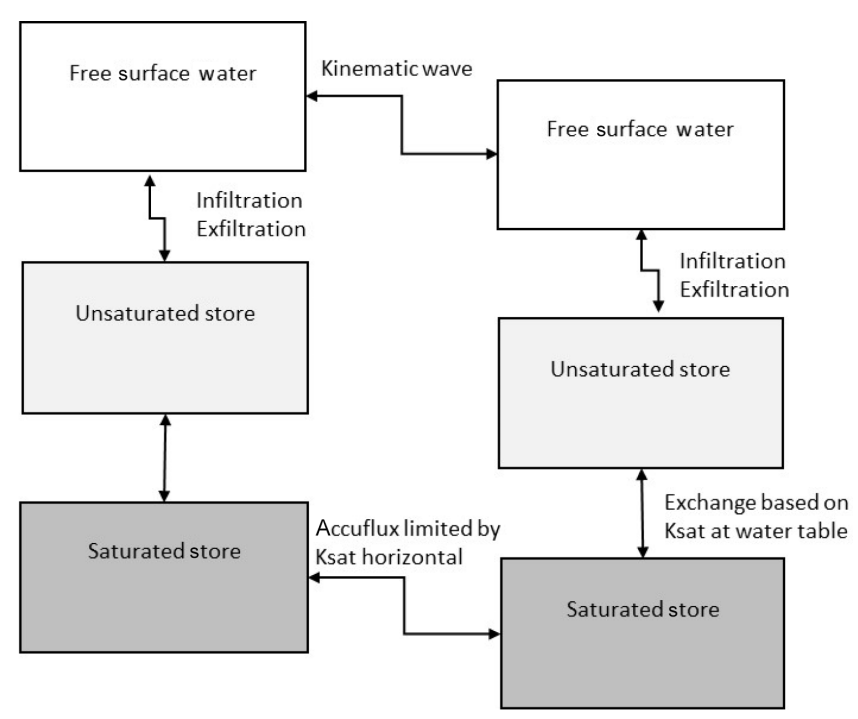

Figure 2. Schematization of the soil within the WFlow_sbm model. Source: http://wflow.readthedocs.io/en/latest/wflow_sbm. $\mathrm{html} /$ the-soil-model.

types. Second, by adjusting the model parameters and evaluate the results.

The performance of the model was assessed using measures of goodness of fit between the modelled and observed flow using the coefficient of determination $\left(R^{2}\right)$ and the Nash-Sutcliffe efficiency (NSE), defined by Nash and Sutcliffe (1970). The observed and the simulated flow of the Dinder and Rahad correlated well, except for few underpredictions and overpredictions of peak flows, which can be explained in terms of inherent uncertainty in the model and the data. However, measures of performances for both calibration and verification runs fell within the acceptable ranges.

\subsection{Indicators of hydrologic alterations (IHA)}

The IHA approach was introduced by Richter et al. (1996). The approach used to assess river ecosystem management objectives which defined based on a statistical representation of the most ecologically relevant hydrologic indicators. These indicators describe the essential characteristics of a river flow that have ecological implications. The IHA method computes 32 hydrologic parameters for each year. For analysing the alteration between two periods, the IHA described in Richter et al. (1996) was applied using the IHA software developed by The Nature of Conservancy (2009).

The general approach is to define hydrologic parameters that characterized the intra-annual variation in the water system condition and then to use the analysis of variations in these parameters as a base for comparing hydrologic alterations of the system before and after the system has been altered by various human activities.

The IHA method has four steps: (a) define the time series of the hydrologic variable (e.g. streamflow) for the two periods to be compared, (b) calculate values for hydrologic parameters, (c) compute intra-annual statistics and (d) calculate values of the IHA by comparing the intra-annual variation before and after the system has been altered and present the results as a percentage of deviation. For assessing hydrologic alteration in the Dinder and Rahad rivers, the flow variations for both rivers have been characterized based on the variations in the streamflow characteristics between three periods: 1972-1986, 1986-1998 and 1998-2011. Temporal variability of streamflow series was analysed at Al Gewisi station on the Dinder River and at Al Hawata station on the Rahad River. A detailed description of IHA can be found in Richter et al. (1996) and Poff et al. (1997).

\section{Results and discussion}

\subsection{LULC classification and change detection}

The overall LULC classification accuracy levels for the four images ranged from 82 to $87 \%$, with Kappa indices of agreement ranging from 77 to $83 \%$ (Table 3 ). The accuracy assessment is based on comparing reference data (class types at specific locations from ground information) to image classification results at the same locations. The overall accuracy of classification is the average value from all classes. The user's accuracy corresponds to errors of inclusion (commission errors), which represents the probability of a pixel classified into a given class actually representing that class on the ground (i.e. from the perspective of the user of the classified map). The producer's accuracy corresponds to errors of exclusion (omission errors), which represents how well refer- 
ence pixels of the ground cover type are classified (i.e. from the perspective of the maker of the classified map). The commission errors occur when an area is included in an incorrect category, while the omission errors occur when an area is excluded from the category to which it belongs. Every error on the map is an omission from the correct class and a commission to an incorrect class (Congalton and Green, 2008). The cross-validation for the land use data from year 2011 was made using the reference data (120 points) collected with a GPS instrument during the field survey (2011-2013). In addition, visual interpretation and historical information obtained from the local people about the land use types in the study area were also used as cross-check validations for old maps. Shrub lands show lower user's and producer's accuracies compared to the other LULC classes. This is mainly due to the mis-classification of some shrub land into woodland, grassland and cropland. This accuracy is satisfactory for the study area considering the multi-temporal analysis of Landsat data and the visual interpretation adapted to image classification.

Landsat image classification results for the years 1972, 1986, 1998 and 2011 are shown in Fig. 3. The large extent of the catchment $\left(77504 \mathrm{~km}^{2}\right)$, and the small-scale of the maps (i.e. 1:4500 000), may not allow distinction of different LULC change patterns by eye. Figure 4 , which shows a closer view of the area, is an example to show multi-temporal changes in the LULC patterns. The zoomed-in areas in the red boxes, shown on a large scale, provide more details of the LULC patterns. This area is located downstream of the Rahad Irrigation Scheme of Sudan, established in 1981. The waterlogging and woodland areas that occurred in 1998 and 2011 resulted from the drainage water of the project accumulating over the years (a clear example of LULC multitemporal change over the Rahad basin). The lower maps show the Google Earth images of the large-scale area. Although the dates of these Google Earth images do not exactly match the ones of the satellite images, they show the part of the dried period in the study area and hence the complexity of the LULC patterns.

According to the produced LULC maps, it was found that woodland, shrub land and grassland were the dominant types of LULC classes for the years 1972, while for the year 1986 they were shrub land, grassland and cropland. The LULC map of 1998 illustrates that the predominant types of LULC classes were cropland and woodland, while they were cropland and shrubs in 2011.

LULCC in the D\&R are assessed by image comparison. In general, the results showed that the dominant process is the large decrease in woodland and increase in cropland. This result was in agreement with that of Rientjes et al. (2011) and Gumindoga et al. (2014), who studied the changes in land cover, rainfall and streamflow in the neighbouring catchment of the upper Gilgel Abbay in Ethiopia.

Table 4 shows the percentages of LULCC classes in Dinder and Rahad basins that occurred in the periods 1972-1986,
1986-1998 and 1998-2011. The decrease in the woodland area in 1986 is mainly attributed to the deforestation during the drought time in 1984 and 1985. As a result, the cropland was increased due to the development of new agricultural areas in both irrigated (i.e. Rahad Agricultural Scheme) and rain-fed sectors. The rapid expansion in the mechanized rain-fed agriculture led to a large increase in cropland during 1998 and 2011. These findings are in agreement with what has been reported by Marcotullio and Onishi (2008) and Biro et al. (2013) from their similar studies conducted in the Ethiopian highlands and the Gedaref region in eastern Sudan.

\subsubsection{Calibration and validation of the hydrological model}

To assess the reliability of the SBRE products, validation is carried out with the use of ground measurements at four gauges in which observed data are available. Two gauges (Gonder and Bahir Dar) are located nearby the upstream part of the catchments in the Ethiopian plateau, while the other two (Gedaref and Al Hawata) are located at the most downstream part of the catchment in the Sudanese lowland. The validation is performed at annual time step. The results show that the difference of RFE against ground measurements has no consistent patterns. TRMM and CHIRPS have shown no consistent patterns at the lowland (Gedaref and Al Hawata), but both products are consistent and overestimate rainfall at the Ethiopian highland (Gonder and Bahir Dar) in all years except 2007 (Fig. 5). Since both the Dinder and the Rahad derive their main flow from the Ethiopian highlands, products with consistent patterns in the highlands will be more suitable for running hydrologic models in this catchment. From these findings, one can conclude that the CHIRPS v2.0 and TRMM 3B42 v7 are more suitable than RFE 2.0 for running hydrologic model. Comparing CHIRPS v2.0 and TRMM $3 \mathrm{~B} 42 \mathrm{v} 7$, it is clear that CHIRPS v2.0 has less overestimation of rainfall. Thus, CHIRPS v2.0 is the best product to be used as a forcing data for hydrologic model in the Dinder and Rahad basins.

The NSE and $R^{2}$ ranged from 0.4 to 0.80 and 0.50 to 0.80 , respectively, for both the daily calibration and validation for the three precipitation products at $\mathrm{Al}$ Gewisi station on the Dinder River and Al Hawata station on the Rahad River (Figs. 6 and 7). At Al Gewisi station, the large underestimation in the first validation period for CHIRPS can be attributed to the underestimation of rainfall by CHIRPS in 2007 at both Gonder and Bahir Dar (Fig. 5), while at the same time CHIRPS overestimates rainfall in all years from 2001 to 2006. Therefore, calibration of the hydrologic model (during the period 2002-2005) resulted in underestimation of river flow in 2007. On the other hand, at Al Hawata station, the difference between observed and model flow in the first period of validation (i.e. 2008) is likely due to an error either 
Table 3. Accuracy assessment (\%) of LULC maps.

\begin{tabular}{lrr|rr|rr|rr}
\hline LULC & \multicolumn{2}{c|}{1972} & \multicolumn{2}{|c|}{1986} & 1998 & 2011 \\
\cline { 2 - 8 } Classes & Producer's & User's & Producer's & User's & Producer's & User's & Producer's & User's \\
\hline Woodland & 88 & 89 & 89 & 90 & 89 & 90 & 91 & 93 \\
Cropland & 78 & 70 & 80 & 74 & 80 & 80 & 83 & 82 \\
Shrub land & 71 & 71 & 73 & 75 & 77 & 75 & 80 & 75 \\
Grassland & 80 & 88 & 83 & 88 & 85 & 88 & 86 & 89 \\
Bare land & 82 & 76 & 82 & 78 & 82 & 78 & 82 & 85 \\
Water & 86 & 86 & 88 & 86 & 91 & 86 & 94 & 86 \\
\hline Overall & 82 & & 84 & & 85 & & 87 \\
Kappa & 77 & & 79 & & 81 & & 83
\end{tabular}

Table 4. Land cover changes (\%) in Dinder and Rahad basins that occurred in the periods 1972-1986, 1986-1998 and 1998-2011.

\begin{tabular}{lrrrr|rrrr}
\hline Land cover & \multicolumn{4}{c|}{ Dinder } & \multicolumn{4}{c}{ Rahad } \\
\cline { 2 - 8 } type (\%) & 1972 & 1986 & 1998 & 2011 & 1972 & 1986 & 1998 & 2011 \\
\hline Bare area & 5 & 1 & 0 & 2 & 6 & 5 & 0 & 3 \\
Woodland & 42 & 23 & 27 & 14 & 35 & 14 & 21 & 14 \\
Shrub land & 23 & 43 & 21 & 36 & 30 & 32 & 13 & 15 \\
Grassland & 16 & 18 & 5 & 1 & 11 & 22 & 9 & 1 \\
Cropland & 14 & 15 & 45 & 47 & 18 & 26 & 55 & 68 \\
\hline
\end{tabular}

in the input data or the observed flow values or a combination of both.

In general, the calibration results indicate that CHIRPS 2.0 is the best product over rugged terrains with complex rainfall patterns, such as those in the D\&R basins. This result is in agreement with Hessels (2015), who compared and validated 10 open-access and spatially distributed satellite rainfall products over the Nile Basin and found that CHIRPS is the best product to be used in the Nile Basin. The modelling results show that the approach is reasonably good and therefore can be used to predict runoff at a sub-basin level. Then the model was used to simulate the impact of LULCC on streamflow by running the model using land cover from different periods of time (1972, 1986, 1998 and 2011) and keeping precipitation (CHIRPS), evapotranspiration and other model parameters without change.

\subsection{Streamflow response under land cover conversions}

After the calibration and validation of the WFlow, the model has been run using different land use data with fixed model parameters: first, with land use data from 1972; second, with land use data from 1986; third, with land use data from 1998; and fourth, with land use data from 2011. Then the output flows from the four land uses were compared. We note that the rainfall (CHIRPS) and PET for the period 2001-2012 were used with the 1972, 1986, 1998 and 2011 land uses to identify hydrological impacts of changes in land cover explicitly.
The WFlow result indicates that streamflow is affected by LULCC in both the Dinder and the Rahad rivers. The effect of LULCC is much larger in the Rahad than in the Dinder. In the Rahad basin, the simulated streamflow showed low peak flow with land use data from 1972 and high flow with land use data from 2011. Woodland and shrub land are dominant in 1972 and occupied 35 and $30 \%$ of the upper catchment area, respectively, while cropland is the dominant land cover type in 2011, occupying $68 \%$. Woodland and shrub land have high porosity and delayed the release of water to the catchment outlet. Woodland removal implies less infiltration due to a decrease in soil permeability, less interception of rainfall by the tree canopies and thus more runoff and high flow peaks. The daily streamflow of the Dinder and the Rahad as results from different LULC are shown in Fig. 8. Figure $9 \mathrm{~b}$ shows the simulated streamflow of the Rahad River as a result of land covers of 1972, 1986, 1998 and 2011. Annual streamflow increased by $75 \%$ between 1972 and 1986, but is followed by a decrease of $45 \%$ between 1986 and 1998 . The increase in streamflow could be a result of a decrease in woodland by $60 \%$ from $35 \%$ in 1972 to $14 \%$ in 1986, associated with an increase in cropland and grassland. Cropland has increased by $44 \%$ from $18 \%$ in 1972 to $26 \%$ in 1986 and grassland has increased by $100 \%$ from $11 \%$ in 1972 to $22 \%$ in 1986 . This increase in grassland thus decreases water infiltration due to soil compaction caused by grazing, which causes both higher runoff and an increase in annual streamflow magnitude. During the period 1986-1998, cropland and woodland showed a significant increase by 113 and 

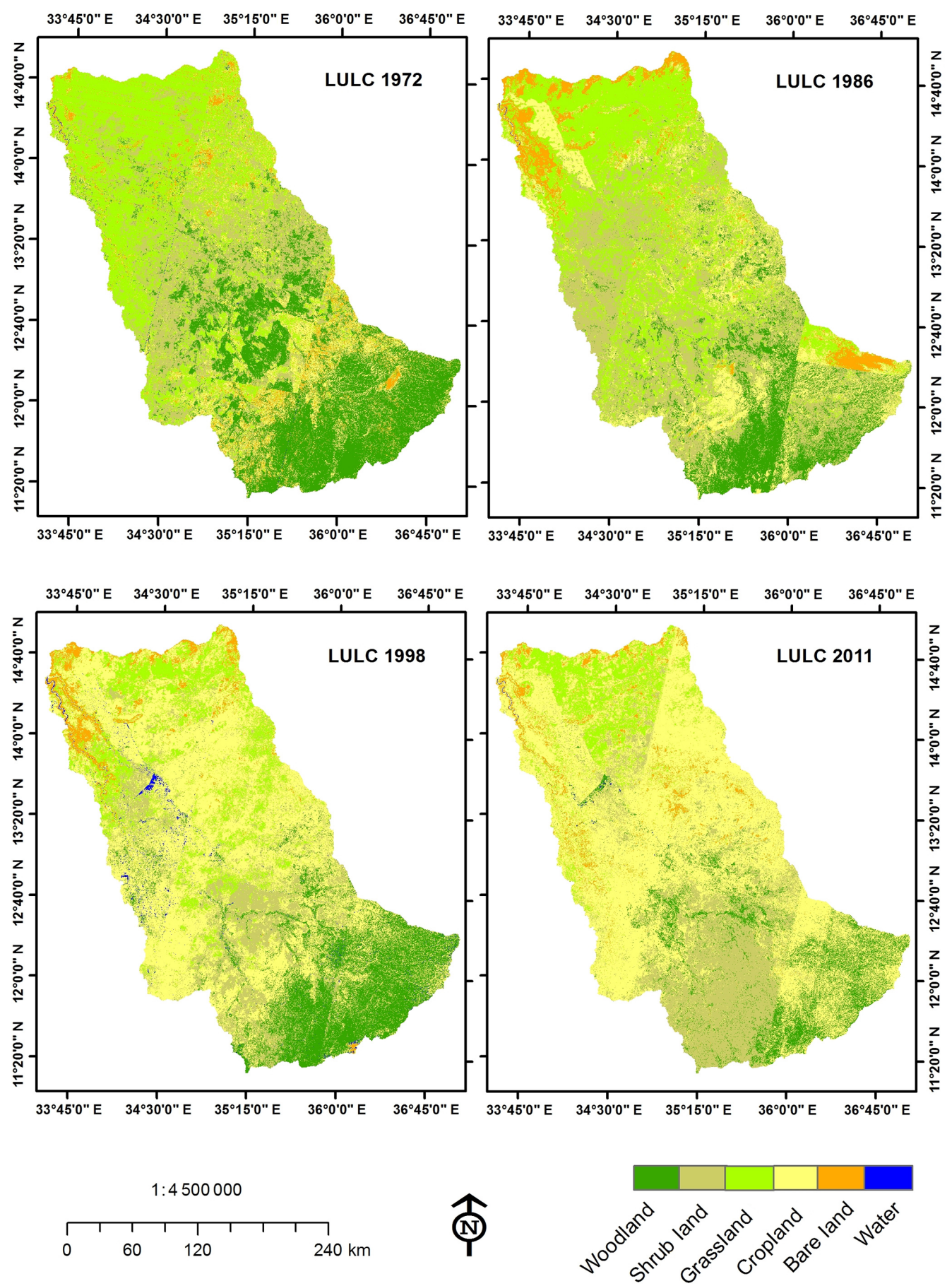

Figure 3. Classified LULC maps of the years 1972, 1986, 1998 and 2011.

$53 \%$, respectively, while the remaining categories showed declines. During the period 1998-2011, the annual streamflow increased by $65 \%$ and corresponds with results on increases in the percentage of bare land, cropland and shrub land by 754,23 and $15 \%$, respectively, while a decrease in woodland and grassland by 37 and $94 \%$, respectively.
Similar to the Rahad, the simulated streamflow of the Dinder River showed low peak flow with land use data from 1972 and relatively high flow with land use data from 2011. Woodland is dominant in 1972 and occupied $42 \%$ of the total catchment area, while cropland is the dominant land cover type in 2011, occupying $47 \%$. Figure 9 a shows the simulated annual streamflow of the Dinder River as a result of land 

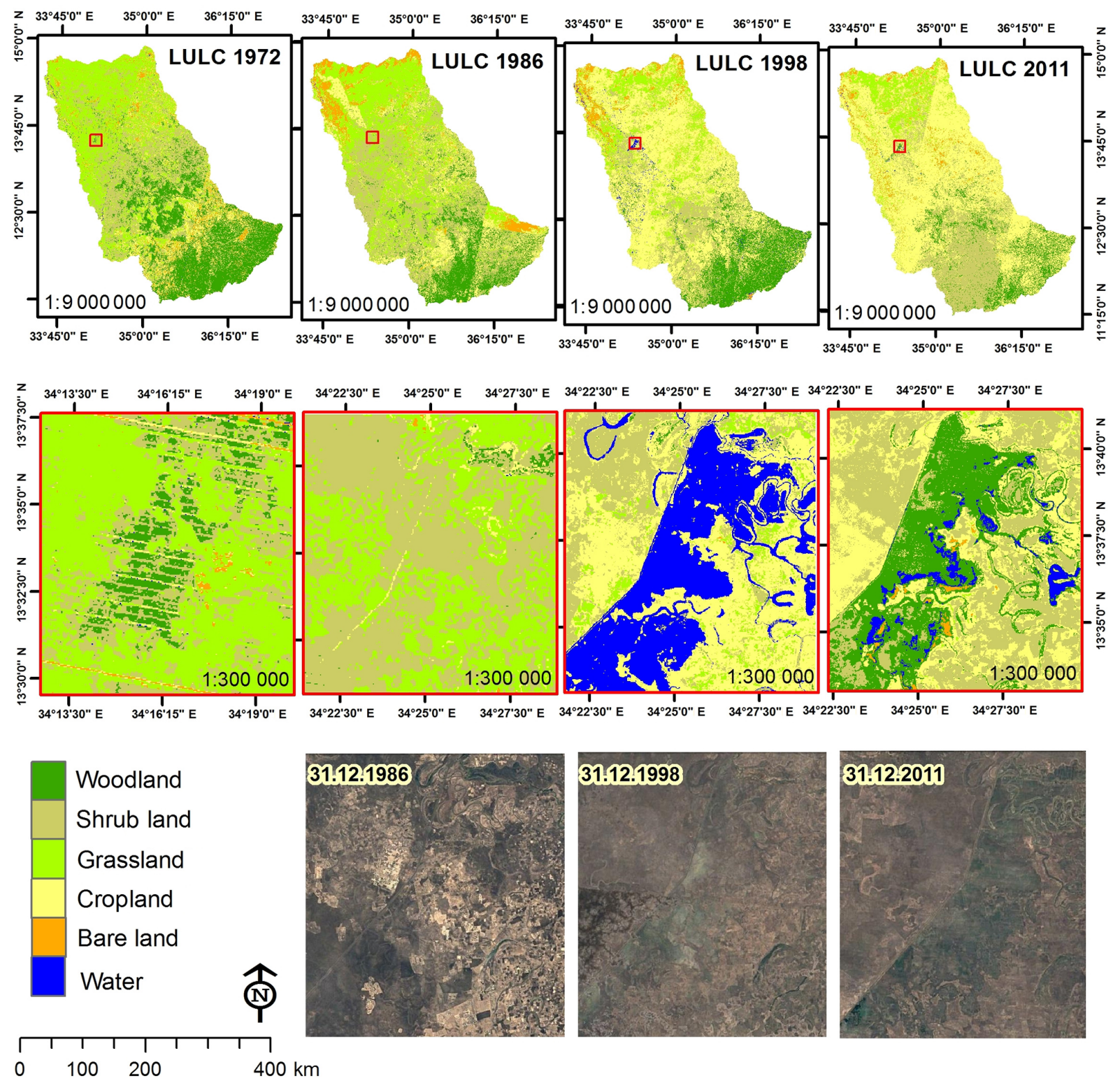

Figure 4. Classified LULC maps of the years 1972, 1986, 1998 and 2011. The areas in the red boxes provide more details of the LULCC patterns.

cover data of 1972, 1986, 1998 and 2011. Annual streamflow increased by $20 \%$ between 1972 and 1986 but is followed by a decrease of $9 \%$ between 1986 and 1998. This could be a result of a decrease in woodland by $43 \%$ from $42 \%$ in 1972 to $23 \%$ in 1986 associated with an increase in shrub land, grassland and cropland by 83,10 and $6 \%$, respectively. During the period 1986-1998, cropland and woodland increased by 192 and $16 \%$, respectively, while the remaining categories showed declines. Over the period 1998-2011, the annual streamflow increased by $52 \%$ and corresponds with findings on increases in the percentage of bare land, cropland and shrub land by 360,4 and $71 \%$, respectively, while a decrease in woodland and grassland by 50 , and $76 \%$, re- spectively. The decrease in percentage change of bare area over the period 1986-1998, along with the increase in woodland in both the Dinder and the Rahad basins, indicates that the environment was recovering from the severe drought of 1984-1985.

In addition to the streamflow response to LULCC, evapotranspiration (ET) is another important component of the water balance that constitutes a major determinant of the amounts of water draining from different land cover types within the catchment. The ET result shows high rates of actual evapotranspiration (AET) when running the model with land cover data from the years 1972 and 1998 at both the subcatchments and over the entire catchment (Tables 5 and 6). 
Gedaref

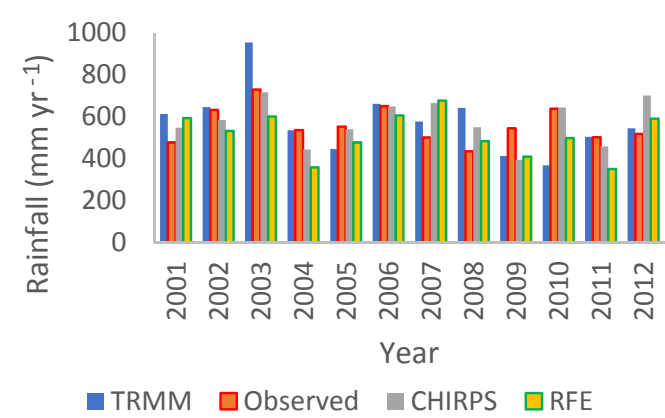

Gonder

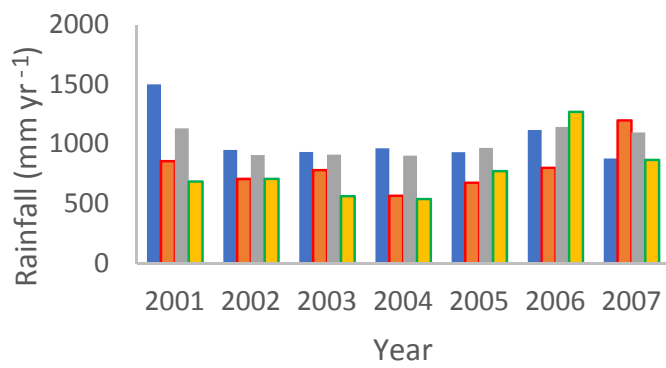

- TRMM $\square$ Observed $\square$ CHIRPS $\square$ RFE
Al Hawata

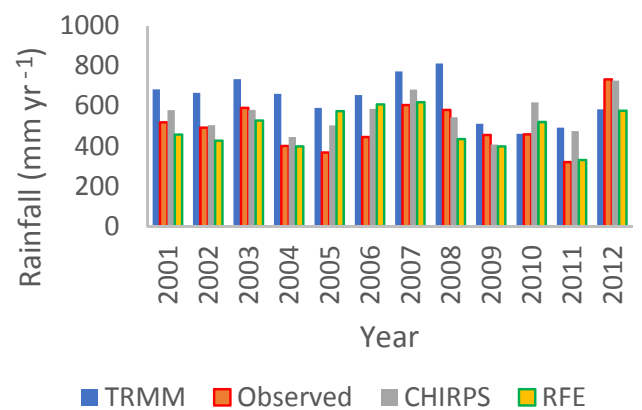

Bahir Dar

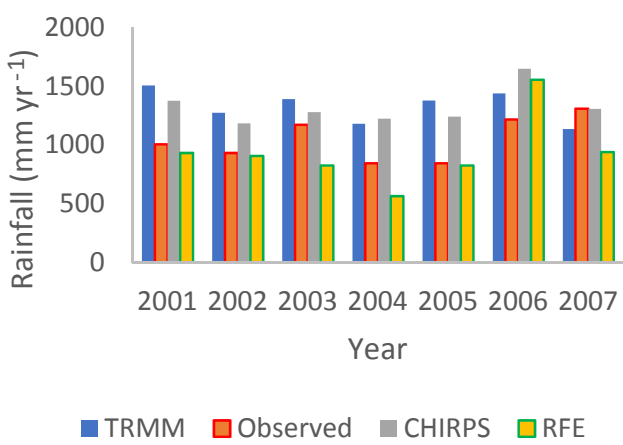

Figure 5. Comparison of SBRE products with ground measurements at four locations.

This can be attributed to the large percentage coverage of woodland in 1972 and 1998 compared to land cover data from 1986 and 2011 (please refer to Table 4). The lowest AET is observed when running the model with land cover data from 1986. This is likely due to the severe drought during the mid-1980s that limits the water availability and decreases the green coverage. Table 5 presents the change in the annual average AET at sub-catchment level as a response to LULCC for the Dinder catchment. Table 6 shows the changes in water balance for the entire Dinder and Rahad catchments when running the hydrologic model with different LULC and fixed rainfall data for the periods 2001-2012.

Since both the Dinder and the Rahad rivers are seasonal, their flows mainly depend on rainfall patterns and magnitudes. In addition to the effect of LULCC on the streamflow, Fig. 10 shows that the annual variability of rainfall is another factor affecting the annual patterns of the streamflow.

\subsection{Streamflow analysis with IHA}

Since both Dinder and Rahad are seasonal rivers (JulyNovember) and its floodplains, including the mayas, are mainly depending on floods, the streamflow analysis is focused on the flows during the months of high flows and the indicators describing the hydrological high extremes. The in- vestigated streamflow variables are a subset of the 32 indicators proposed by Richter et al. (1996) under the range of variability approach (RVA) that characterizes the natural flow regime of a river into five categories of magnitude, timing, duration, frequency and rate of change. In this section, we analysed the modelled streamflow as a result of LULC data from 1972, 1986, 1998 and 2011.

\subsubsection{Magnitude of monthly flow}

The general pattern of median monthly flow of the Rahad River (Fig. 11a) at Al Hawata station during 1972-1986 is that the median flow increased in all months of flow (JulyNovember) with an average of $83 \%$ per month. In contrast, the median monthly flow decreased in all months during the period 1986-1998 with an average of $45 \%$ per month. Similar to the period 1972-1986, the median monthly flow during 1998-2011 increased by an average of $65 \%$ per month. In comparison to Rahad, the Dinder median monthly flow (Fig. 11b) at Al Gewisi station during 1972-1986 increased in all months of flow by an average of $21 \%$ per month. In contrast, the median monthly flow decreased in all months during the period 1986-1998 with an average of $6 \%$ per month. Likewise, to the period from 1972-1986, the median monthly flow during 1998-2011 increased by an av- 
(a)

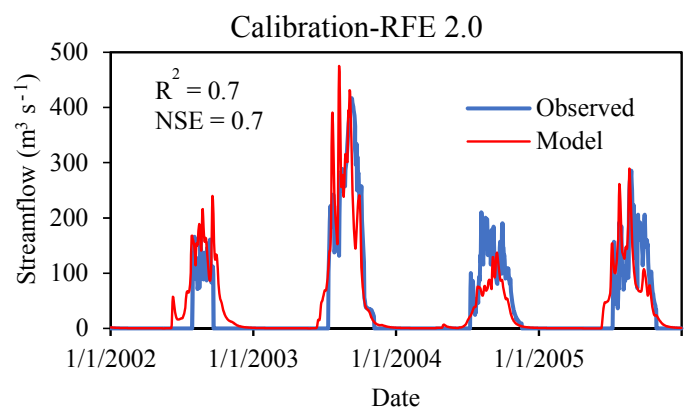

(c)

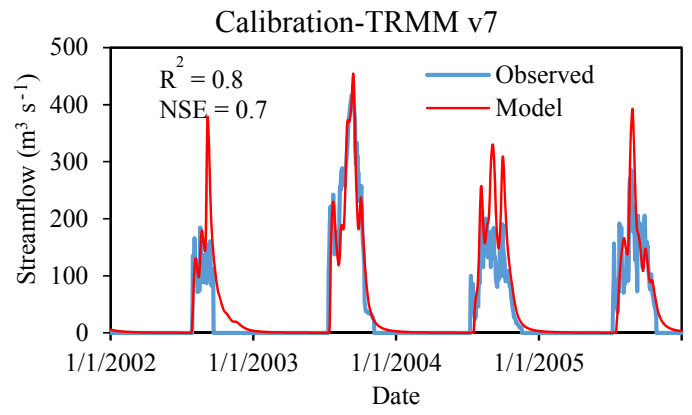

(e)

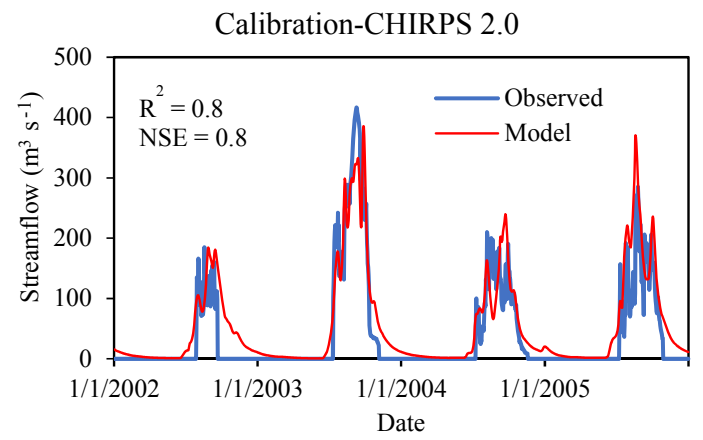

(b)

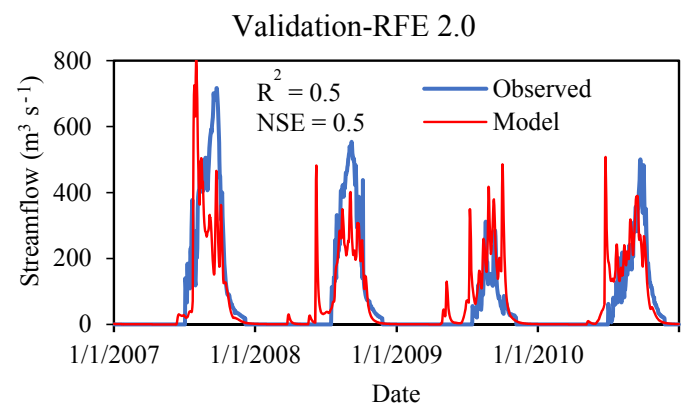

(d)

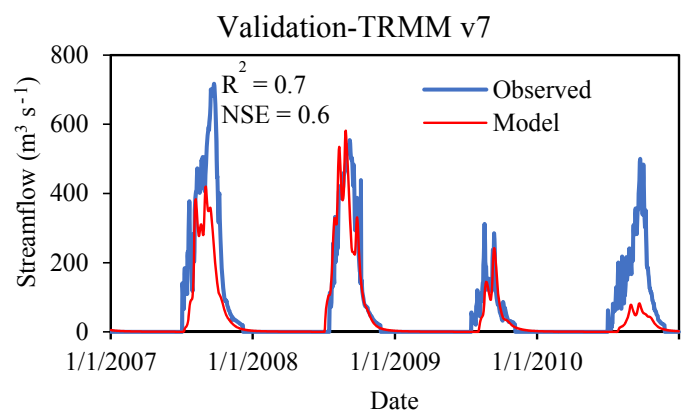

(f)

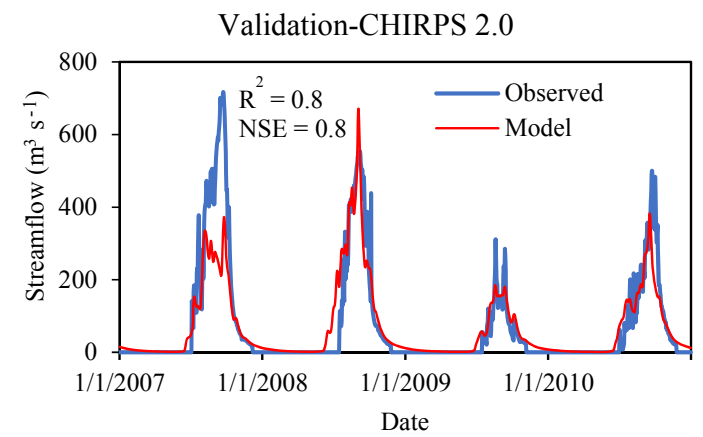

Figure 6. Calibration and validation results at Al Gewisi station on Dinder River (a) and (b) for RFE, (c) and (d) for TRMM and (e) and (f) for CHIRPS.

erage of $17 \%$ per month. Alterations of the monthly flow magnitude, particularly during the months of high flows (August-October) is likely affecting habitat availability on floodplains, which may lead to decreases and/or disappearance of native flora and increases in non-native flora that might not be suitable for the herbivorous wildlife that dwells in the DNP.

\subsubsection{Magnitude of river extreme floods}

Extreme floods are important in re-forming both the biological and physical structure of a river and its associated floodplain. Extreme floods are also important in the formation of key habitats such as oxbow lakes and floodplain wetlands. The pattern of the extreme flow is vital for the filling of wetland mayas of the DNP. Therefore, annual flow maxima of $1,7,30$ and 90 days have been investigated. The median maxima are presented in Fig. 12. In general, all results have shown that the maxima are significantly affected by LULCC. In Rahad, median flow maxima for 1, 7, 30 and 90 day intervals from the land use data from 1986 are 51, 56, 67 and $68 \%$, respectively, higher than the maxima from the land use data from 1972. Likewise, median flow maxima for 1, 7, 30 and 90 day intervals from the land use data from 2011 are 32, 33,36 and $39 \%$, respectively, higher than the maxima from the land use data from 1998. In contrast, median flow max- 
(a)

Calibration-RFE 2.0

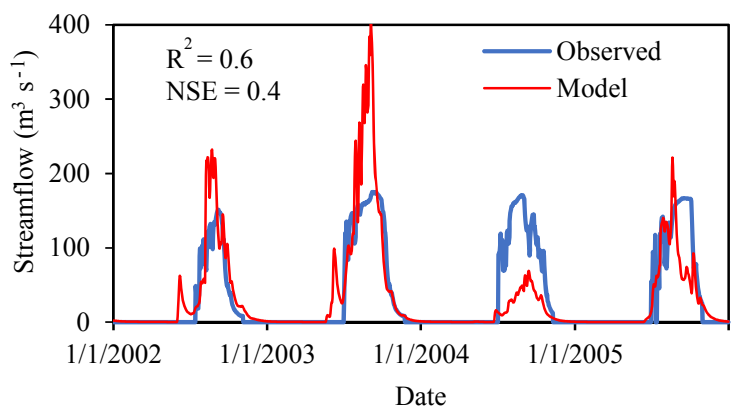

(c)

Calibration-TRMM v7

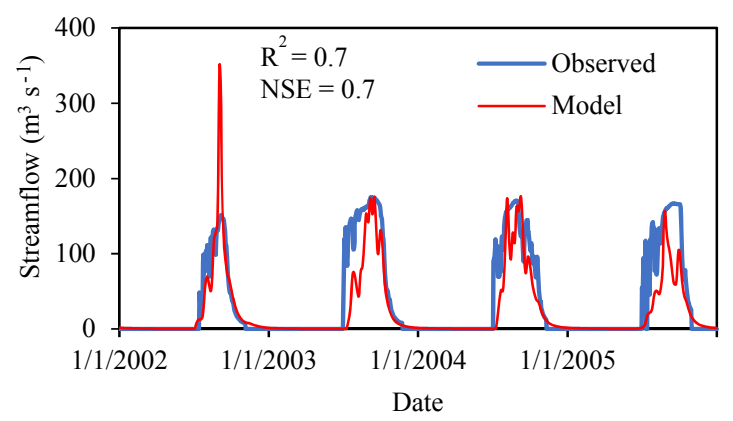

(e)

Calibration-CHIRPS 2.0

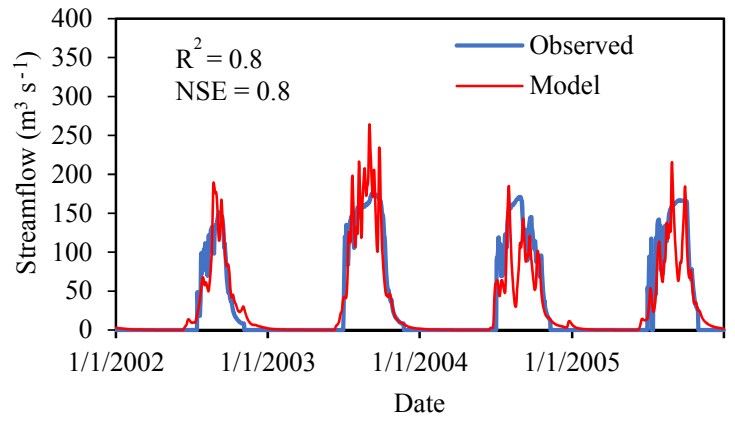

(b)

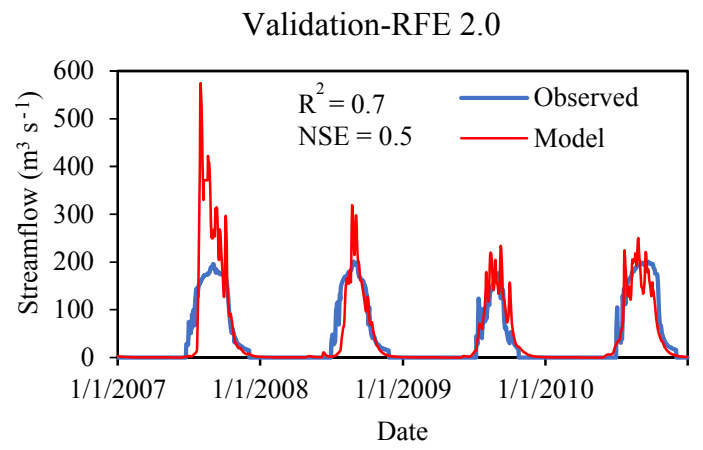

(d)

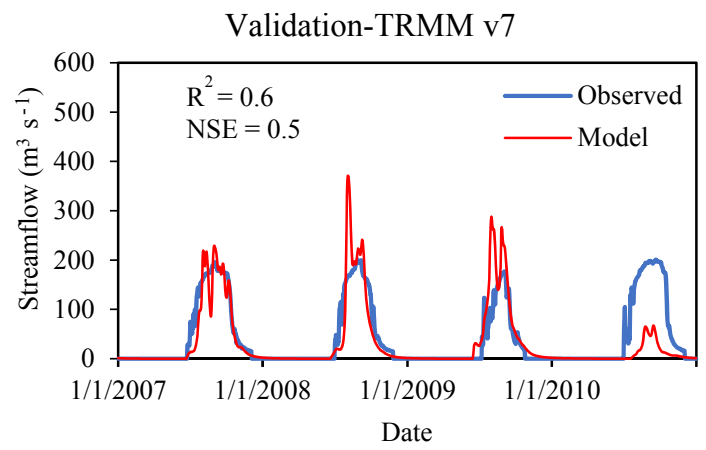

(f)

Validation-CHIRPS 2.0

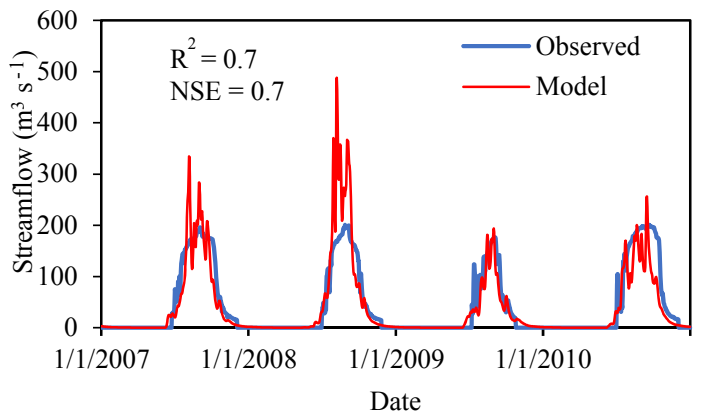

Figure 7. Calibration and validation results at Al Hawata station on Rahad River (a) and (b) for RFE, (c) and (d) for TRMM and (e) and (f) for CHIRPS.

ima for 1, 7, 30 and 90 day intervals from the land use data from 1998 are 39, 39, 42 and $42 \%$, respectively, lower than the maxima from the land use data from 1986.

In the Dinder River the effect of LULCC on streamflow is not big as in Rahad River. This is likely due to the large expansion in cropland in the Rahad catchment to $68 \%$ of the total area compared to $47 \%$ in the Dinder catchment. The median flow maxima for $1,7,30$ and 90 day intervals from the land use data from 1986 are 19,19, 18 and $18 \%$, respec- tively, higher than the maxima from the land use data from 1972. Likewise, the median flow maxima for 1, 7, 30 and 90 day intervals from the land use data from 2011 are 14, 13, 14 and $19 \%$ respectively, higher than the maxima from the land use data from 1998. In contrast, the median flow maxima for 1, 7, 30 and 90 day intervals from the land use data from 1998 are 11, 11, 10 and $10 \%$, respectively, lower than the maxima from the land use data from 1986. Peak flows are the critical aspects of the lateral connectivity between the 
(a)

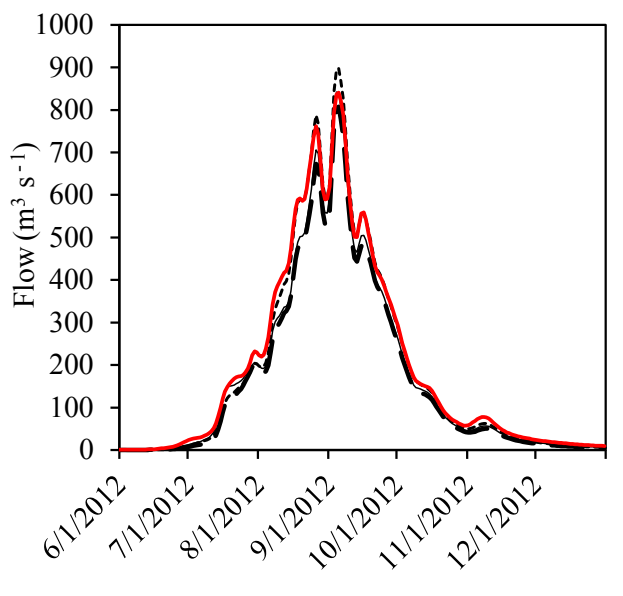

Date (b)

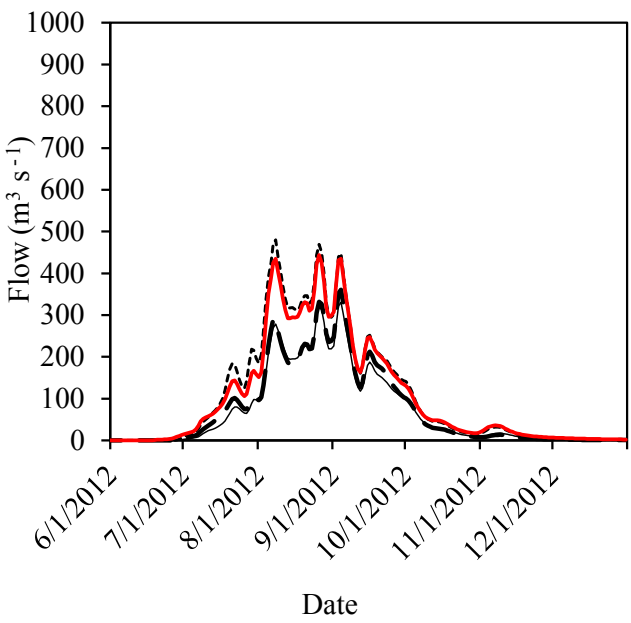

- - Streamflow from land use of 1972
- Streamflow from land use of 1986
Streamflow from land use of 1998
Streamflow from land use of 2011

Figure 8. Daily streamflow results from the WFlow model at (a) Al Gewisi station on the Dinder River and (b) Al Hawata station on the Rahad River based on land use from 1972, 1986, 1998 and 2011 for the year 2012 as an example.

(a)

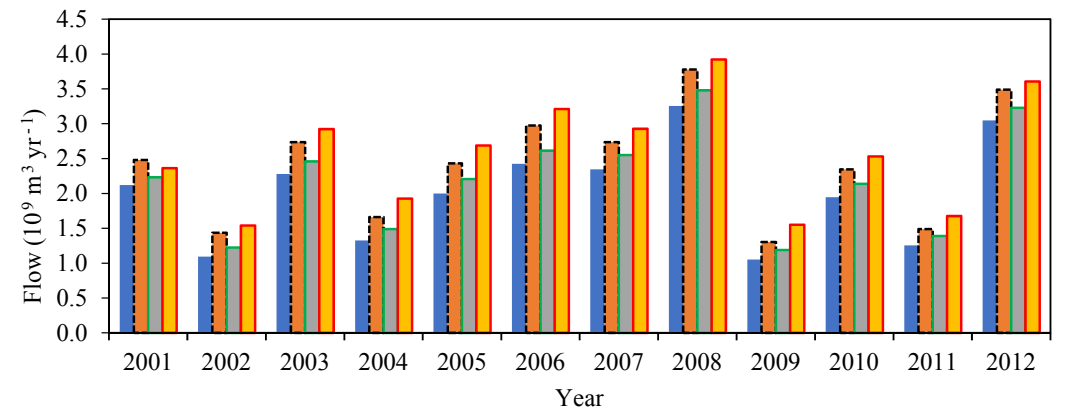

(b)

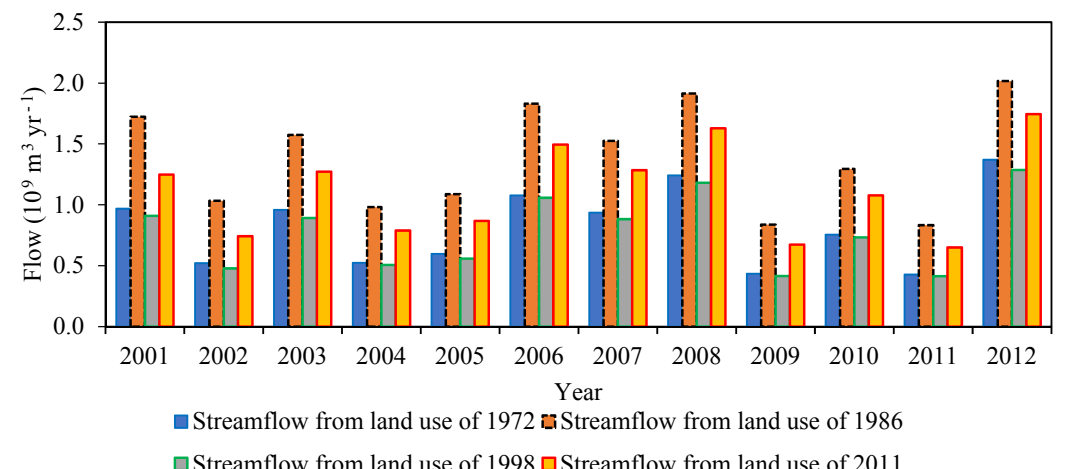

Figure 9. Annual streamflow results from the WFlow model at (a) Al Gewisi station on the Dinder River and (b) Al Hawata station on the Rahad River based on land use from 1972, 1986, 1998 and 2011. 
(a)

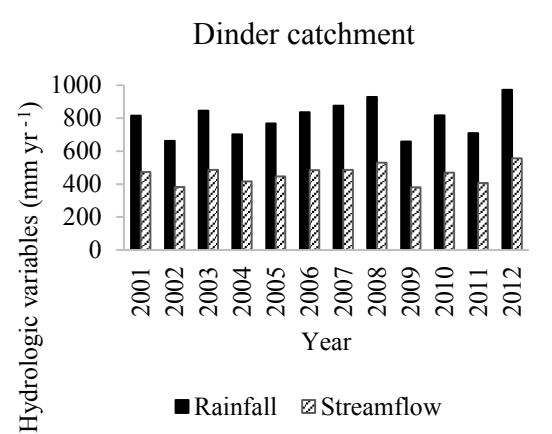

(b)

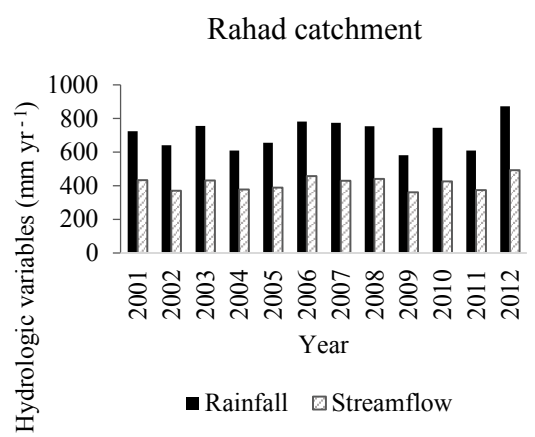

Figure 10. Annual average rainfall and streamflow patterns and magnitudes for the years 2001-2012, (a) for the Dinder catchment and (b) for Rahad catchment.

Table 5. Annual average AET as a response to LULCC at the sub-catchment level for the Dinder catchment (1972-1986).

\begin{tabular}{rrrrr|rrrr}
\hline & \multicolumn{3}{c}{ AET from land cover data from 1972 $(\mathrm{mm})$} & \multicolumn{4}{c}{ AET from land cover data from 1986 (mm) } \\
\cline { 2 - 8 } Year & Al Gewisi & Musa & Gelagu & Upper Dinder & Al Gewisi & Musa & Gelagu & Upper Dinder \\
\hline 2001 & 558 & 583 & 626 & 464 & 426 & 424 & 396 & 288 \\
2002 & 443 & 456 & 535 & 510 & 322 & 317 & 306 & 312 \\
2003 & 564 & 639 & 642 & 486 & 425 & 469 & 405 & 312 \\
2004 & 455 & 502 & 573 & 500 & 326 & 354 & 340 & 311 \\
2005 & 504 & 547 & 575 & 505 & 376 & 396 & 358 & 323 \\
2006 & 527 & 576 & 632 & 545 & 396 & 414 & 406 & 359 \\
2007 & 598 & 602 & 618 & 564 & 468 & 444 & 400 & 382 \\
2008 & 593 & 689 & 703 & 576 & 459 & 513 & 471 & 392 \\
2009 & 421 & 482 & 519 & 516 & 310 & 343 & 302 & 323 \\
2010 & 536 & 566 & 606 & 520 & 412 & 415 & 383 & 331 \\
2011 & 470 & 467 & 554 & 530 & 350 & 327 & 329 & 332 \\
2012 & 636 & 679 & 684 & 542 & 500 & 504 & 450 & 353 \\
\hline
\end{tabular}

Rahad and the Dinder rivers and its floodplains. Reduction of the magnitude of these high-flow peaks during dry years (less than average) may reduce the ecological function of the mayas wetlands areas as breeding, nursery and feeding habitat for wildlife.

\subsubsection{Timing of annual extreme floods}

Synchronization of annual flooding with a variety of riverine and floodplain species life-cycle requirements is likely to be of high importance given the adaptation of species to their habitat. In the Rahad River, dates of the annual maxima as results from the land use data from 1972, 1986, 1998 and 2011 occurred within the same 3 weeks (15 August-2 September, Julian date (JD) 227-245). The annual maxima from the land use data from 1986 is 18 days earlier than the annual maxima from land use data from 1972. This could be attributed to land cover degradation and deforestation due to the devastating drought of 1984-1985 resulting in acceleration of the runoff response.
In Dinder River, dates of the annual maxima are not affected by LULCC and occurred within the same 2 days (1112 September, JD 254-255).

\subsubsection{Rate of change in flow}

The rate of change in flow can affect persistence and lifetime for both aquatic and riparian species (Poff et al., 1997), particularly in arid areas where streamflow usually changes rapidly in a very short time. Figure 13 shows the rate of flow rises and flow falls for both Rahad and Dinder. The median rate of flow rises (positive differences between consecutive daily values) in Rahad River has increased by $74 \%$ from $2.73 \mathrm{~m}^{3} \mathrm{~s}^{-1}$ day $^{-1}$ in 1972 to $4.73 \mathrm{~m}^{3} \mathrm{~s}^{-1}$ day $^{-1}$ in 1986 In 1998 the median rate of flow rises decreased by $50 \%$, while increasing by $37 \%$ in 2011 . Similarly, the median rate of flow falls (negative differences between consecutive daily values) has increased by $88 \%$ from $0.12 \mathrm{~m}^{3} \mathrm{~s}^{-1}$ day $^{-1}$ in 1972 to $0.23 \mathrm{~m}^{3} \mathrm{~s}^{-1}$ day $^{-1}$ in 1986 . In 1998 the median rate of flow falls decreased by $37 \%$, while increasing by $22 \%$ in 2011. Likewise, the median rate of flow rises and flow falls in 
Table 6. Water balance of the Dinder and Rahad catchments applying different LULC data.

\begin{tabular}{|c|c|c|c|c|c|c|c|c|c|}
\hline \multicolumn{2}{|c|}{ Dinder catchment } & \multicolumn{2}{|c|}{ Land cover data from 1972} & \multicolumn{2}{|c|}{ Land cover data from 1986} & \multicolumn{2}{|c|}{ Land cover data from 1998} & \multicolumn{2}{|c|}{ Land cover data from 2011} \\
\hline Year & $\begin{array}{r}\text { Rainfall } \\
(\mathrm{mm})\end{array}$ & $\begin{array}{r}\text { AET } \\
(\mathrm{mm})\end{array}$ & $\begin{array}{r}\text { Streamflow } \\
(\mathrm{mm})\end{array}$ & $\begin{array}{r}\text { AET } \\
(\mathrm{mm})\end{array}$ & $\begin{array}{r}\text { Streamflow } \\
(\mathrm{mm})\end{array}$ & $\begin{array}{l}\text { AET } \\
(\mathrm{mm})\end{array}$ & $\begin{array}{r}\text { Streamflow } \\
(\mathrm{mm})\end{array}$ & $\begin{array}{l}\text { AET } \\
(\mathrm{mm})\end{array}$ & $\begin{array}{r}\text { Streamflow } \\
(\mathrm{mm})\end{array}$ \\
\hline 2001 & 816 & 558 & 258 & 383 & 433 & 432 & 384 & 496 & 320 \\
\hline 2002 & 663 & 486 & 177 & 314 & 349 & 364 & 299 & 430 & 233 \\
\hline 2003 & 847 & 583 & 264 & 403 & 444 & 449 & 397 & 519 & 327 \\
\hline 2004 & 703 & 507 & 195 & 333 & 370 & 374 & 329 & 451 & 252 \\
\hline 2005 & 768 & 532 & 236 & 363 & 405 & 414 & 354 & 479 & 289 \\
\hline 2006 & 835 & 570 & 265 & 394 & 441 & 441 & 395 & 513 & 322 \\
\hline 2007 & 876 & 595 & 280 & 424 & 452 & 476 & 400 & 540 & 336 \\
\hline 2008 & 929 & 640 & 289 & 459 & 470 & 509 & 420 & 582 & 347 \\
\hline 2009 & 659 & 484 & 175 & 319 & 340 & 363 & 297 & 435 & 225 \\
\hline 2010 & 817 & 557 & 260 & 385 & 432 & 432 & 386 & 505 & 312 \\
\hline 2011 & 710 & 505 & 205 & 334 & 376 & 377 & 333 & 454 & 256 \\
\hline 2012 & 972 & 635 & 337 & 452 & 520 & 498 & 474 & 579 & 393 \\
\hline \multicolumn{2}{|c|}{ Rahad catchment } & \multicolumn{2}{|c|}{ Land cover data from 1972} & \multicolumn{2}{|c|}{ Land cover data from 1986} & \multicolumn{2}{|c|}{ Land cover data from 1998} & \multicolumn{2}{|c|}{ Land cover data from 2011} \\
\hline Year & $\begin{array}{r}\text { Rainfall } \\
(\mathrm{mm})\end{array}$ & $\begin{array}{l}\text { AET } \\
(\mathrm{mm})\end{array}$ & $\begin{array}{r}\text { Streamflow } \\
(\mathrm{mm})\end{array}$ & $\begin{array}{l}\text { AET } \\
(\mathrm{mm})\end{array}$ & $\begin{array}{r}\text { Streamflow } \\
(\mathrm{mm})\end{array}$ & $\begin{array}{l}\text { AET } \\
(\mathrm{mm})\end{array}$ & $\begin{array}{r}\text { Streamflow } \\
(\mathrm{mm})\end{array}$ & $\begin{array}{l}\text { AET } \\
(\mathrm{mm})\end{array}$ & $\begin{array}{r}\text { Streamflow } \\
(\mathrm{mm})\end{array}$ \\
\hline 2001 & 724 & 409 & 315 & 290 & 434 & 398 & 326 & 309 & 416 \\
\hline 2002 & 641 & 398 & 243 & 271 & 370 & 383 & 258 & 291 & 350 \\
\hline 2003 & 755 & 450 & 305 & 323 & 432 & 434 & 322 & 342 & 413 \\
\hline 2004 & 609 & 360 & 249 & 231 & 378 & 338 & 270 & 244 & 364 \\
\hline 2005 & 656 & 399 & 258 & 267 & 389 & 378 & 278 & 285 & 372 \\
\hline 2006 & 782 & 450 & 332 & 324 & 457 & 431 & 351 & 336 & 446 \\
\hline 2007 & 774 & 473 & 301 & 344 & 430 & 456 & 319 & 363 & 411 \\
\hline 2008 & 754 & 438 & 315 & 313 & 441 & 415 & 338 & 322 & 431 \\
\hline 2009 & 581 & 352 & 229 & 220 & 361 & 333 & 248 & 238 & 343 \\
\hline 2010 & 744 & 449 & 295 & 319 & 425 & 431 & 313 & 335 & 409 \\
\hline 2011 & 610 & 369 & 241 & 235 & 375 & 348 & 262 & 252 & 358 \\
\hline 2012 & 873 & 507 & 366 & 381 & 492 & 485 & 388 & 390 & 483 \\
\hline
\end{tabular}

(a)

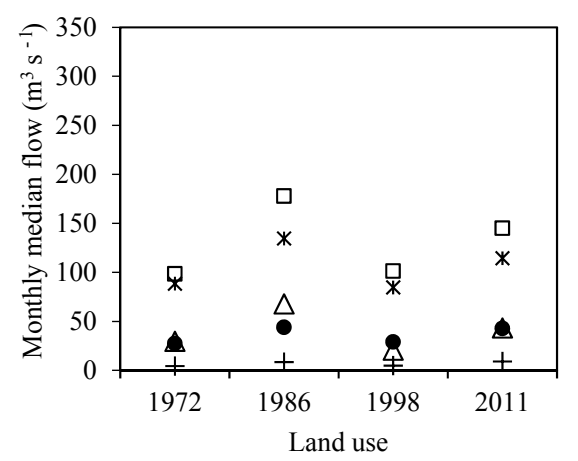

(b)

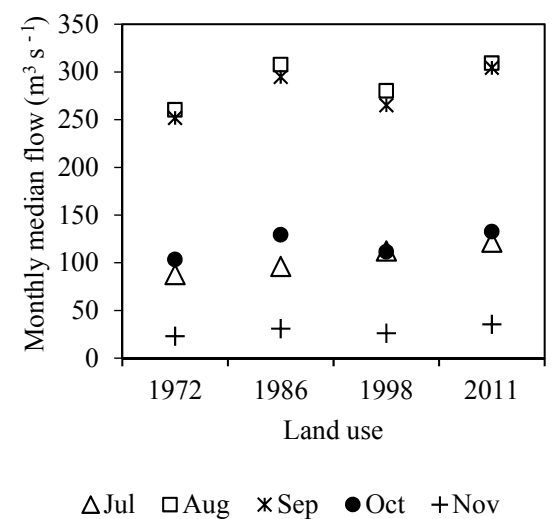

Figure 11. The monthly median flow (a) for Rahad River and (b) for Dinder River.

the Dinder River follows the same pattern of the Rahad flow, but no significant changes were observed. This result shows that the fluctuation in rate of change in streamflow is strongly linked to LULCC, especially when analysing the streamflow as a result of land use after a period of drought (e.g. land use data from 1986). 
(a)

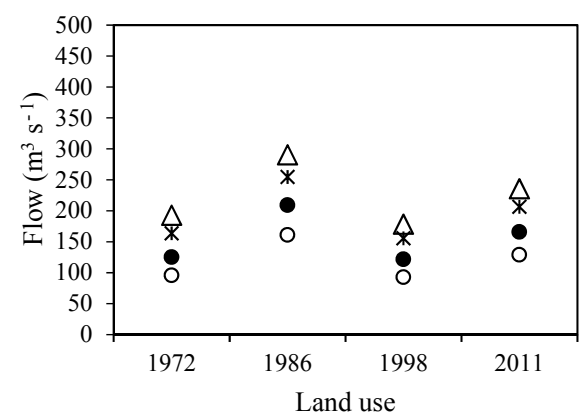

(b)

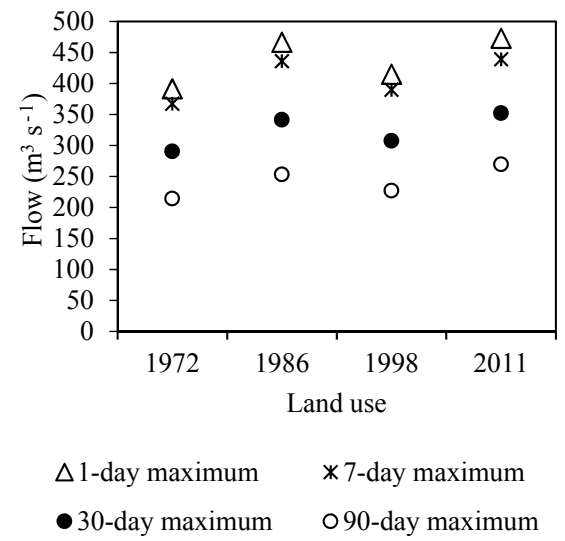

Figure 12. Median flow maxima for 1, 7, 30 and 90 day intervals from the land use data from 1972, 1986, 1998 and 2011 for (a) Rahad River and (b) Dinder River.

(a)

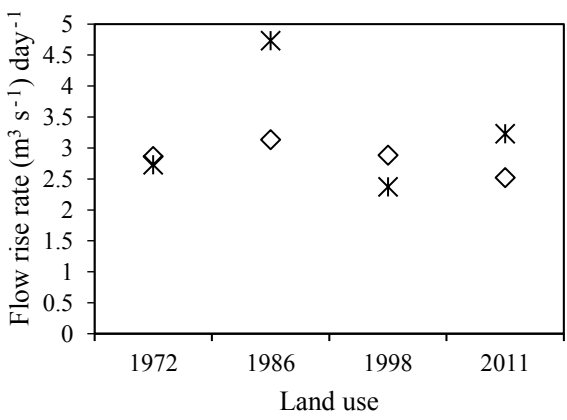

(b)

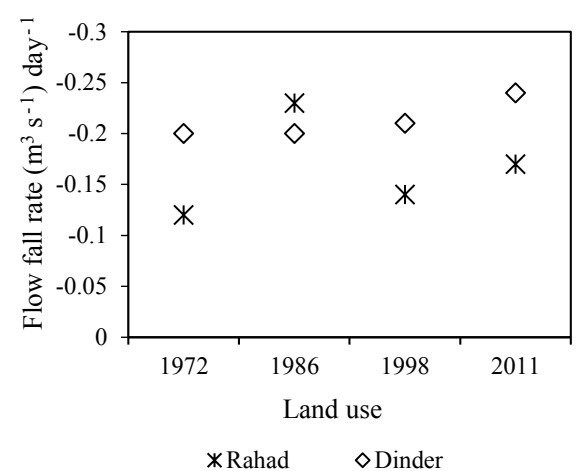

Figure 13. The rate of flow rises (a) and falls (b) as a response to land use data from 1972, 1986, 1998 and 2011 for both Rahad and Dinder rivers (negative sign in the vertical axis indicates downward direction of flow).

\section{Conclusions}

For assessing the changes in land cover, four remote sensing images were used for the years 1972, 1986, 1998 and 2011. The accuracy assessment with supervised land cover classification shows that the classification results are reliable. The land cover changes in the D\&R are assessed by image comparison and the results showed that the dominant process is the relatively large decrease in woodland and the large increase in cropland. Results of LULCC detection between 1972 and 2011 indicate a significant decrease in woodland and an increase in cropland. Woodland decreased from 42 to $14 \%$ and from 35 to $14 \%$ for Dinder and Rahad, respectively. Cropland increased from 14 to $47 \%$ and from 18 to $68 \%$ in Dinder and Rahad, respectively. The rate of deforestation is high during the period 1972-1986 and is probably due to the severe drought during 1984-1985 and expansion of agricultural activities as well as increased demand for wood for fuel, construction and other human needs due to the increase in population. On the other hand, the increase in woodland during the period between 1986 and 1998 is probably due to reforestation activities in the basin. Nevertheless, the magnitude of deforestation is still much larger than the reforestation. The cropland expansion over the period 19861998 is larger than the expansion over the period 1998-2011, suggesting that most of the areas that are suitable for cultivation have most likely been occupied, or the land tenure regulations have controlled the expansion of cultivation by local communities.

The results of the hydrological model indicate that streamflow is affected by LULCC in both the Dinder and the Rahad rivers. The effect of LULCC on streamflow is significant during 1986 and 2011, particularly in the Rahad River. This could be attributed to the severe drought during 1984-1985 and the large expansion in cropland in the Rahad catchment to $68 \%$ of the total area.

The IHA analysis indicated that the flow of the Dinder and the Rahad rivers was associated with significant upward 
and downward alterations in magnitude, timing and rate of change of river flows, as a result of LULCC. These alterations in the streamflow characteristics are likely to have significant effects on a range of species that depend on the seasonal patterns of flow. Therefore, alterations in the magnitude of the annual floods that decrease the water flowing to the mayas may reduce the production of native river-floodplain fauna and flora and the migration of animals that may be connected to mayas inundation.

Data availability. All research data including DEM, soil, land use and land cover, rainfall and evapotranspiration data were obtained from the open-access datasets that are freely available on the internet, and can be accessed through the URLs provided within the research text. 


\section{Appendix A}

\section{A1 The WFlow_sbm interception model}

The analytical model of rainfall interception is based on Rutter's numerical model (see Gash, 1979, and Gash et al., 1995, for a full description). The simplifications that Gash (1979) introduced allow the model to be applied on a daily basis. The amount of water needed to completely saturate the canopy $\left(P^{\prime}\right)$ is defined as follows:

$P^{\prime}=\frac{-\bar{R} S}{\bar{E}_{\mathrm{w}}} \ln \left[1-\frac{\bar{E}_{\mathrm{w}}}{\bar{R}}\left(1-p-p_{\mathrm{t}}\right)^{-1}\right]$,

where $\bar{R}$ is the average precipitation on a saturated canopy $\left(\mathrm{mm}\right.$ day $\left.^{-1}\right), \bar{E}_{\mathrm{w}}$ is the average evaporation from the wet canopy $\left(\mathrm{mm} \mathrm{day}^{-1}\right), S$ is canopy storage capacity $(\mathrm{mm}), p$ is the free throughfall coefficient (the proportion of rain which falls to the ground without sticking the canopy) and $p_{\mathrm{t}}$ is the proportion of rain that is diverted to stemflow (-).

Interception losses from the stems are calculated for days with $P \geq S_{\mathrm{t}} / P_{\mathrm{t}} . S_{\mathrm{t}}$ (trunk water capacity; $\mathrm{mm}$ ) and $P_{\mathrm{t}}$ are small and neglected in the WFlow_sbm model. In applying the analytical model, saturated conditions are assumed to occur when the hourly rainfall exceeds a certain threshold. A threshold of $0.5 \mathrm{~mm} \mathrm{~h}^{-1}$ is often used (Gash, 1979). $\bar{R}$ is calculated for all hours when the rainfall exceeds the threshold to give an estimate of the mean rainfall rate onto a saturated canopy. $E_{\mathrm{w}}$ is then calculated using the Rutter model.

\section{A2 The WFlow_sbm soil water accounting scheme}

Within the soil model, the soil is considered as a bucket with a certain depth $\left(Z_{\mathrm{t}}\right)$, divided into a saturated store $(S)$ and an unsaturated store $(U)$, the capacity of each expressed in units of depth. The top of the saturated store forms a pseudo-water table at depth $\left(Z_{i}\right)$ such that the value of $(S)$ at any time is given by the following:

$S=\left(z_{\mathrm{t}}-z_{i}\right)\left(\theta_{\mathrm{s}}-\theta_{\mathrm{r}}\right)$,

where $\theta_{\mathrm{S}}$ and $\theta_{\mathrm{r}}$ are the saturated and residual soil water contents, respectively.

The unsaturated store $(U)$ is subdivided into storage $\left(U_{\mathrm{s}}\right)$ and deficit $\left(U_{\mathrm{d}}\right)$ which are also expressed in units of depth:

$U_{\mathrm{d}}=\left(\theta_{\mathrm{s}}-\theta_{\mathrm{r}}\right) z_{i}-U$

and

$U_{\mathrm{s}}=U-U_{\mathrm{d}}$.

The saturation deficit $\left(S_{\mathrm{d}}\right)$ for the whole soil profile is defined as follows:

$S_{\mathrm{d}}=\left(\theta_{\mathrm{s}}-\theta_{\mathrm{r}}\right) z_{\mathrm{t}}-S$.
Infiltrating rainfall enters the unsaturated store first. The transfer of water from the unsaturated store to the saturated store (st) is controlled by the saturated hydraulic conductivity $K_{\text {sat }}$ at depth $\left(Z_{i}\right)$ and the ratio between $U_{\mathrm{s}}$ and $S_{\mathrm{d}}$.

$\mathrm{st}=K_{\mathrm{sat}} \frac{U_{\mathrm{s}}}{S_{\mathrm{d}}}$

As the saturation deficit becomes smaller, the rate of the transfer between the unsaturated and saturated stores increases. Saturated conductivity $\left(K_{\text {sat }}\right)$ declines with soil depth $(z)$ in the model according to the following:

$K_{\text {sat }}=K_{0} e^{(-f z)}$,

where: where $K_{0}$ is the saturated conductivity at the soil surface $\left(\mathrm{m} \mathrm{day}^{-1}\right)$ and $f$ is a scaling parameter $\left(\mathrm{m}^{-1}\right)$.

The scaling parameter $f$ is defined by the following:

$f=\frac{\theta_{\mathrm{s}}-\theta_{\mathrm{r}}}{M}$,

where $M$ is a soil parameter determining the decrease in saturated conductivity with depth (m).

The saturated store can be drained laterally via subsurface flow according to the following:

$\mathrm{sf}=K_{0} \tan (\beta) e^{-S_{\mathrm{d}} / M}$,

where $\beta$ is element slope angle (degrees) and sf is the calculated subsurface flow $\left(\mathrm{m}^{2}\right.$ day $\left.^{-1}\right)$.

The original SBM model does not include transpiration or a notion of capillary rise. In WFlow_sbm, transpiration is first taken from the saturated store if the roots reach the water table $\left(Z_{i}\right)$. If the saturated store cannot satisfy the demand, the unsaturated store is used next. First the number of wet roots (WR) is determined (going from 1 to 0 ) using a sigmoid function as follows:

$\mathrm{WR}=1.0 /\left(1.0+e^{-\mathrm{SN}(\mathrm{WT}-\mathrm{RT})}\right)$,

where $\mathrm{SN}$ is sharpness parameters, WT is water table $(\mathrm{mm})$ and RT is rooting depth ( $\mathrm{mm}$ ).

The sharpness parameter (by default a large negative value, -80000 ) is a parameter that determines if there is a stepwise output or a more gradual output (default is stepwise). Water table is the level of the water table in the grid cell below the surface and rooting depth is the maximum depth of the roots below the surface. For all values of water tables smaller that rooting depth a value of 1 is returned, if they are equal to rooting depth a value of 0.5 is returned, and if the water table is larger than the rooting depth a value of zero is returned. The returned wet root (WR) fraction is multiplied by the potential evaporation (and limited by the available water in saturated store) to get the transpiration from the saturated part of the soil. Next the remaining potential evaporation is used to extract water from the unsaturated store. 
Capillary rise is determined using the following approach: first the $K_{\text {sat }}$ is determined at the water table $\left(Z_{i}\right)$; next a potential capillary rise is determined from the minimum of the $K_{\text {sat }}$, the actual transpiration taken from the unsaturated store, the available water in the saturated store and the deficit of the unsaturated store. Finally, the potential rise is scaled using the distance between the roots and the water table using the following:

$\mathrm{CS}=\mathrm{CSF} /\left(\mathrm{CSF}+z_{i}-\mathrm{RT}\right)$,

in which CS is the scaling factor with which the potential rise is multiplied, CSF is a model parameter (default $=100$ ) and RT is the rooting depth. If the roots reach the water table (RT $>Z_{i}$ ) CS is set to zero, thus setting the capillary rise to zero. A detailed description of the TOPOG_SBM model has been provided by Vertessy and Elsenbeer (1999). 


\section{Appendix B}

Table B1. Wflow model parameter's description.

\begin{tabular}{|c|c|c|}
\hline Parameter name in Wflow & Description & Unit \\
\hline CanopyGapFraction & $\begin{array}{l}\text { Gash interception model parameter: the free } \\
\text { throughfall coefficient. } \\
\text { Fraction of precipitation that does not hit the } \\
\text { canopy directly. }\end{array}$ & $(-)$ \\
\hline EoverR (E/R) & $\begin{array}{l}\text { Gash interception model parameter. } \\
\text { Ratio of average wet canopy evaporation rate over } \\
\text { average precipitation rate. }\end{array}$ & $(-)$ \\
\hline MaxCanopyStorage & $\begin{array}{l}\text { Canopy storage. } \\
\text { Used in the Gash interception model. }\end{array}$ & $(\mathrm{mm})$ \\
\hline FirstZoneCapacity & Maximum capacity of the saturated store. & $(\mathrm{mm})$ \\
\hline FirstZoneKsatVer & $\begin{array}{l}\text { Saturated conductivity of the store at the surface. } \\
\text { The M parameter determines how this decreases } \\
\text { with depth. }\end{array}$ & $(\mathrm{mm})$ \\
\hline FirstZoneMinCapacity & Minimum capacity of the saturated store. & $(\mathrm{mm})$ \\
\hline InfiltCapPath & $\begin{array}{l}\text { Infiltration capacity of the compacted soil fraction } \\
\text { of each grid cell. }\end{array}$ & $\left(m m\right.$ day $\left.^{-1}\right)$ \\
\hline InfiltCapSoil & $\begin{array}{l}\text { Infiltration capacity of the non-compacted soil } \\
\text { fraction of each grid cell. }\end{array}$ & $\left(m m\right.$ day $\left.^{-1}\right)$ \\
\hline M & $\begin{array}{l}\text { Soil parameter determining the decrease in satu- } \\
\text { rated conductivity with depth. }\end{array}$ & $(\mathrm{m})$ \\
\hline $\mathrm{N}$ & $\begin{array}{l}\text { Manning } \mathrm{N} \text { parameter for the kinematic wave } \\
\text { function. }\end{array}$ & \\
\hline N_river & Manning's parameter for cells marked as river. & \\
\hline LeafAreaIndex & $\begin{array}{l}\text { Total one-side green leaf area per ground surface } \\
\text { area. }\end{array}$ & $(-)$ \\
\hline Albedo & $\begin{array}{l}\text { Reflectivity of earth surface: the ratio of radiation } \\
\text { reflected to the radiation incident on a surface. }\end{array}$ & $(-)$ \\
\hline Beta & Element slope angle. & (degree) \\
\hline rootdistpar & $\begin{array}{l}\text { Sharpness parameter determine how roots are } \\
\text { linked to water table. }\end{array}$ & $(\mathrm{mm})$ \\
\hline PathFrac & Fraction of compacted area per grid cell. & $(-)$ \\
\hline RootingDepth & Rooting depth of the vegetation. & $(\mathrm{mm})$ \\
\hline CapScale & Scaling factor in the capillary rise calculations. & $\left(m m\right.$ day $\left.^{-1}\right)$ \\
\hline RunoffGeneratingGWPerc & $\begin{array}{l}\text { Fraction of the soil depth that contributes to sub- } \\
\text { cell runoff. }\end{array}$ & $(-)$ \\
\hline thetaR & Residual water content. & $(-)$ \\
\hline thetaS & Water content at saturation (porosity). & $(-)$ \\
\hline
\end{tabular}




\section{Appendix C}

Table C1. Wflow model parameters calibrated values.

\begin{tabular}{|c|c|c|c|}
\hline $\begin{array}{l}\text { Albedo } \\
\text { Land cover }\end{array}$ & Sub-catchment & Soil type & Value \\
\hline 1 & {$[0,>$} & {$[0,>$} & 0.40 \\
\hline 2 & {$[0,>$} & {$[0,>$} & 0.20 \\
\hline 3 & {$[0,>$} & {$[0,>$} & 0.16 \\
\hline 4 & {$[0,>$} & {$[0,>$} & 0.26 \\
\hline 5 & {$[0,>$} & {$[0,>$} & 0.25 \\
\hline 6 & {$[0,>$} & {$[0,>$} & 0.10 \\
\hline \multicolumn{4}{|l|}{ EoverR } \\
\hline Land cover & Sub-catchment & Soil type & Value \\
\hline 1 & {$[0,>$} & {$[0,>$} & 0.0 \\
\hline 2 & {$[0,>$} & {$[0,>$} & 0.3 \\
\hline 3 & {$[0,>$} & {$[0,>$} & 0.2 \\
\hline 4 & {$[0,>$} & {$[0,>$} & 0.2 \\
\hline 5 & {$[0,>$} & {$[0,>$} & 0.1 \\
\hline 6 & {$[0,>$} & {$[0,>$} & 0.0 \\
\hline \multicolumn{4}{|l|}{ FirstZoneKsatVer } \\
\hline Land cover & Sub-catchment & Soil type & Value \\
\hline$[0,>$ & {$[0,>$} & 1 & 511 \\
\hline$[0,>$ & {$[0,>$} & 2 & 600 \\
\hline$[0,>$ & {$[0,>$} & 3 & 543 \\
\hline$[0,>$ & {$[0,>$} & 4 & 525 \\
\hline$[0,>$ & {$[0,>$} & 5 & 586 \\
\hline$[0,>$ & {$[0,>$} & 6 & 576 \\
\hline$[0,>$ & {$[0,>$} & 7 & 540 \\
\hline \multicolumn{4}{|l|}{ InfiltCapPath } \\
\hline Land cover & Sub-catchment & Soil type & Value \\
\hline$[0,>$ & {$[0,>$} & 1 & 5 \\
\hline$[0,>$ & {$[0,>$} & 2 & 21 \\
\hline$[0,>$ & {$[0,>$} & 3 & 5 \\
\hline$[0,>$ & {$[0,>$} & 4 & 32 \\
\hline$[0,>$ & {$[0,>$} & 5 & 34 \\
\hline$[0,>$ & {$[0,>$} & 6 & 5 \\
\hline$[0,>$ & {$[0,>$} & 7 & 21 \\
\hline \multicolumn{4}{|l|}{ LeafAreaIndex } \\
\hline Land cover & Sub-catchment & Soil type & Value \\
\hline 1 & {$[0,>$} & {$[0,>$} & 0.0 \\
\hline 2 & {$[0,>$} & {$[0,>$} & 8.8 \\
\hline 3 & {$[0,>$} & {$[0,>$} & 7.0 \\
\hline 4 & {$[0,>$} & {$[0,>$} & 0.6 \\
\hline 5 & {$[0,>$} & {$[0,>$} & 0.7 \\
\hline 6 & {$[0,>$} & {$[0,>$} & 0.0 \\
\hline $\begin{array}{l}\text { MaxCanopyStorage } \\
\text { Land cover }\end{array}$ & Sub-catchment & Soil type & Value \\
\hline 1 & {$[0,>$} & {$[0,>$} & 0.00 \\
\hline 2 & {$[0,>$} & {$[0,>$} & 0.336 \\
\hline 3 & {$[0,>$} & {$[0,>$} & 0.21 \\
\hline 4 & {$[0,>$} & {$[0,>$} & 0.25 \\
\hline 5 & {$[0,>$} & {$[0,>$} & 0.34 \\
\hline 6 & {$[0,>$} & {$[0,>$} & 0.00 \\
\hline
\end{tabular}


Table C1. Continued.

\begin{tabular}{llll}
\hline $\begin{array}{l}\text { CanopyGapFraction } \\
\text { Land cover }\end{array}$ & Sub-catchment & Soil type & Value \\
\hline 1 & {$[0,>$} & {$[0,>$} & 1.0 \\
2 & {$[0,>$} & {$[0,>$} & 0.2 \\
3 & {$[0,>$} & {$[0,>$} & 0.6 \\
4 & {$[0,>$} & {$[0,>$} & 0.5 \\
5 & {$[0,>$} & {$[0,>$} & 0.4 \\
6 & {$[0,>$} & {$[0,>$} & 0.5 \\
\hline
\end{tabular}

\begin{tabular}{llll}
\hline $\begin{array}{l}\text { FirstZoneCapacity } \\
\text { Land cover }\end{array}$ & Sub-catchment & Soil type & Value \\
\hline$[0,>$ & {$[0,>$} & 1 & 44500 \\
{$[0,>$} & {$[0,>$} & 2 & 42000 \\
{$[0,>$} & {$[0,>$} & 3 & 44500 \\
{$[0,>$} & {$[0,>$} & 4 & 39000 \\
{$[0,>$} & {$[0,>$} & 5 & 44000 \\
{$[0,>$} & {$[0,>$} & 6 & 42000 \\
{$[0,>$} & {$[0,>$} & 7 & 44500
\end{tabular}

\begin{tabular}{|c|c|c|c|}
\hline $\begin{array}{l}\text { FirstZoneMinCapacity } \\
\text { Land cover }\end{array}$ & Sub-catchment & Soil type & Value \\
\hline$[0,>$ & {$[0,>$} & 1 & 125 \\
\hline$[0,>$ & {$[0,>$} & 2 & 50 \\
\hline$[0,>$ & {$[0,>$} & 3 & 137.5 \\
\hline$[0,>$ & {$[0,>$} & 4 & 33 \\
\hline$[0,>$ & {$[0,>$} & 5 & 87.5 \\
\hline$[0,>$ & {$[0,>$} & 6 & 60 \\
\hline$[0,>$ & {$[0,>$} & 7 & 70 \\
\hline \multicolumn{3}{|l|}{ InfiltCapSoil } & Value \\
\hline$[0,>$ & {$[0,>$} & 1 & 24 \\
\hline$[0,>$ & {$[0,>$} & 2 & 103 \\
\hline$[0,>$ & {$[0,>$} & 3 & 24 \\
\hline$[0,>$ & {$[0,>$} & 4 & 158 \\
\hline$[0,>$ & {$[0,>$} & 5 & 170 \\
\hline$[0,>$ & {$[0,>$} & 6 & 100 \\
\hline$[0,>$ & {$[0,>$} & 7 & 103 \\
\hline \multicolumn{4}{|l|}{$\mathrm{M}$} \\
\hline Land cover & Sub-catchment & Soil type & Value \\
\hline$[0,>$ & {$[0,>$} & 1 & 100 \\
\hline$[0,>$ & {$[0,>$} & 2 & 87 \\
\hline$[0,>$ & {$[0,>$} & 3 & 100 \\
\hline$[0,>$ & {$[0,>$} & 4 & 77 \\
\hline$[0,>$ & {$[0,>$} & 5 & 100 \\
\hline$[0,>$ & {$[0,>$} & 6 & 100 \\
\hline$[0,>$ & {$[0,>$} & 7 & 100 \\
\hline \multicolumn{4}{|l|}{$\mathrm{N}$} \\
\hline Land cover & Sub-catchment & Soil type & Value \\
\hline 1 & {$[0,>$} & {$[0,>$} & 0.42 \\
\hline 2 & {$[0,>$} & {$[0,>$} & 0.80 \\
\hline 3 & {$[0,>$} & {$[0,>$} & 0.70 \\
\hline 4 & {$[0,>$} & {$[0,>$} & 0.65 \\
\hline 5 & {$[0,>$} & {$[0,>$} & 0.80 \\
\hline 6 & {$[0,>$} & {$[0,>$} & 0.12 \\
\hline
\end{tabular}


Table C1. Continued.

\begin{tabular}{|c|c|c|c|}
\hline $\begin{array}{l}\text { PathFrac } \\
\text { Land cover }\end{array}$ & Sub-catchment & Soil type & Value \\
\hline$[0,>$ & {$[0,>$} & 1 & 0.06 \\
\hline$[0,>$ & {$[0,>$} & 2 & 0.09 \\
\hline$[0,>$ & {$[0,>$} & 3 & 0.05 \\
\hline$[0,>$ & {$[0,>$} & 4 & 0.06 \\
\hline$[0,>$ & {$[0,>$} & 5 & 0.06 \\
\hline$[0,>$ & {$[0,>$} & 6 & 0.07 \\
\hline$[0,>$ & {$[0,>$} & 7 & 0.08 \\
\hline \multicolumn{4}{|l|}{ thetaR } \\
\hline Land cover & Sub-catchment & Soil type & Value \\
\hline$[0,>$ & {$[0,>$} & 1 & 0.15 \\
\hline$[0,>$ & {$[0,>$} & 2 & 0.09 \\
\hline$[0,>$ & {$[0,>$} & 3 & 0.19 \\
\hline$[0,>$ & {$[0,>$} & 4 & 0.09 \\
\hline$[0,>$ & {$[0,>$} & 5 & 0.11 \\
\hline$[0,>$ & {$[0,>$} & 6 & 0.09 \\
\hline$[0,>$ & {$[0,>$} & 7 & 0.08 \\
\hline \multicolumn{4}{|l|}{ RunoffGeneratingGWPerc } \\
\hline$[0,>$ & {$[0,>$} & {$[0,>$} & 0.1 \\
\hline \multicolumn{4}{|l|}{ N_River } \\
\hline Land cover & Sub-catchment & Soil type & Value \\
\hline$[0,>$ & {$[0,>$} & {$[0,>$} & 0.035 \\
\hline \multicolumn{4}{|l|}{ CapScale } \\
\hline$[0,>$ & {$[0,>$} & {$[0,>$} & 100 \\
\hline \multicolumn{4}{|l|}{ RootingDepth } \\
\hline Land cover & Sub-catchment & Soil type & Value \\
\hline 1 & {$[0,>$} & {$[0,>$} & 1000 \\
\hline 2 & {$[0,>$} & {$[0,>$} & 1800 \\
\hline 3 & {$[0,>$} & {$[0,>$} & 1400 \\
\hline 4 & {$[0,>$} & {$[0,>$} & 1600 \\
\hline 5 & {$[0,>$} & {$[0,>$} & 200 \\
\hline 6 & {$[0,>$} & {$[0,>$} & 0 \\
\hline \multicolumn{4}{|l|}{ thetaS } \\
\hline Land cover & Sub-catchment & Soil type & Value \\
\hline$[0,>$ & {$[0,>$} & 1 & 0.5 \\
\hline$[0,>$ & {$[0,>$} & 2 & 0.2 \\
\hline$[0,>$ & {$[0,>$} & 3 & 0.5 \\
\hline$[0,>$ & {$[0,>$} & 4 & 0.3 \\
\hline$[0,>$ & {$[0,>$} & 5 & 0.4 \\
\hline$[0,>$ & {$[0,>$} & 6 & 0.2 \\
\hline$[0,>$ & {$[0,>$} & 7 & 0.2 \\
\hline \multicolumn{4}{|l|}{ rootdistpar } \\
\hline Land cover & Sub-catchment & Soil type & Value \\
\hline$[0,>$ & {$[0,>$} & {$[0,>$} & -80000 \\
\hline \multicolumn{4}{|l|}{ Beta } \\
\hline Land cover & Sub-catchment & Soil type & Value \\
\hline$[0,>$ & {$[0,>$} & {$[0,>$} & 0.6 \\
\hline
\end{tabular}


Competing interests. The third author is a member of the editorial board of the journal.

Acknowledgements. This study was carried out as part of a $\mathrm{PhD}$ research program by the first author entitled "The impacts of land degradation on the Dinder and Rahad hydrology and morphology, and linkage to the ecohydrological system of the Dinder National Park, Sudan", which is funded by the Netherland Fellowship Program (NFP). We also thank the Hydraulics Research Center of the Ministry of Water Resources, Irrigation and Electricity Sudan for providing the hydrological data.

Edited by: Uwe Ehret

Reviewed by: two anonymous referees

\section{References}

Bates, P. and De Roo, A.: A simple raster-based model for flood inundation simulation, J. Hydrol., 236, 54-77, 2000.

Bewket, W. and Sterk, G.: Dynamics in land cover and its effect on stream flow in the Chemoga watershed, Blue Nile basin, Ethiopia, Hydrol. Process., 19, 445-458, 2005.

Bewket, W. and Teferi, E.: Assessment of soil erosion hazard and prioritization for treatment at the watershed level: Case study in the Chemoga watershed, Blue Nile basin, Ethiopia, Land Degrad. Dev., 20, 609-622, 2009.

Biro, K., Pradhan, B., Buchroithner, M., and Makeschin, F.: Land use/land cover change analysis and its impact on soil properties in the northern part of Gadarif region, Sudan, Land Degrad. Dev., 24, 90-102, 2013.

Block, P. and Rajagopalan, B.: Interannual variability and ensemble forecast of Upper Blue Nile Basin Kiremt season precipitation, J. Hydrometeorol., 8, 327-343, 2006.

Congalton, R. G. and Green, K.: Assessing the accuracy of remotely sensed data: principles and practices, CRC press, 2008.

DeFries, R. and Bounoua, L.: Consequences of land use change for ecosystem services: a future unlike the past, GeoJ. Lib., 61, 345351, 2004

DeFries, R. and Eshleman, K.: Land-change and hydrologic processes: a major focus for the future, Hydrol. Process., 18, 2183 2186, 2004.

Deursen van, W. P. A.: Geographical Information Systems and Dynamic Models, Ph.D., NGS Publication 190, Utrecht University, available at: http://www.carthago.nl, 198 pp., 1995.

Ellis, E. A., Baerenklau, K. A., Marcos-Martínez, R., and Chávez, E.: Land use/land cover change dynamics and drivers in a low-grade marginal coffee growing region of Veracruz, Mexico, Agroforest. Syst., 80, 61-84, 2010.

Funk, C. C., Peterson, P. J., Landsfeld, M. F., Pedreros, D. H., Verdin, J. P., Rowland, J. D., Romero, B. E., Husak, G. J., Michaelsen, J. C., and Verdin, A. P.: A quasi-global precipitation time series for drought monitoring, US Geological Survey Data Series, 832, 2014.

Gash, J.: An analytical model of rainfall interception by forests, Q. J. Roy. Meteor. Soc., 105, 43-55, 1979.
Gash, J. H. C., Lloyd, C. R., and Lachaud, G.: Estimating sparse forest rainfall interceptionwith an analytical model, J. Hydrol., 170, 79-86, 1995.

Gumindoga, W., Rientjes, T. H. M., Haile, A. T., and Dube, T.: Predicting streamflow for land cover changes in the Upper Gilgel Abay River Basin, Ethiopia: a TOPMODEL based approach, Phys. Chem. Earth Pt. A/B/C, 76-78, 3-15, https://doi.org/10.1016/j.pce.2014.11.012, 2014.

Hansen, A., DeFries, R., and Turner, W.: Land use change and biodiversity: a synthesis of rates and consequences during the period of satellite imagery, in: Land Change Science: Observing, Monitoring, and Understanding Trajectories of Change on the Earth's Surface, Springer, New York, NY, 277-299, 2004.

Hassaballah, K., Mohamed, Y. A., and Uhlenbrook, S.: The Mayas wetlands of the Dinder and Rahad: tributaries of the Blue Nile Basin (Sudan), in: The Wetland Book: II: Distribution, Description and Conservation, edited by: Finlayson, C. M., Milton, G. R., Prentice, R. C., and Davidson, N. C., Springer, Netherlands, 1-13, 2016.

Hemmavanh, C., Ye, Y., and Yoshida, A.: Forest land use change at trans-boundary Laos-China biodiversity conservation area, J. Geogr. Sci., 20, 889-898, https://doi.org/10.1007/s11442-0100818-1, 2010.

Hessels, T. M.: Comparison and Validation of Several Open Access Remotely Sensed Rainfall Products for the Nile Basin, TU Delft, Delft University of Technology, 2015.

Huffman, G. J. and Bolvin, D. T.: TRMM and other data precipitation data set documentation, NASA, Greenbelt, USA, 1-40, 2013.

Hurni, H., Tato, K., and Zeleke, G.: The implications of changes in population, land use, and land management for surface runoff in the upper Nile basin area of Ethiopia, Mt. Res. Dev., 25, 147154, 2005.

Hurst, H., Black, R., and Simaika, Y.: The Nile Basin, vol. IX, The hydrology of the Blue Nile and Atbara and the Main Nile to Aswan, with reference to some Projects, Ministry of Public Works, Physical Department, Cairo, Egypt, 1959.

Jensen, J. R.: Digital Change Detection, Introductory Digital Image Processing: A Remote Sensing Perspective, Prentice Hall, Upper Saddle River, NY, 525 pp., 2005.

Kamusoko, C. and Aniya, M.: Hybrid classification of Landsat data and GIS for land use/cover change analysis of the Bindura district, Zimbabwe, Int. J. Remote Sens., 30, 97-115, 2009.

Karssenberg, D.: The value of environmental modelling languages for building distributed hydrological models, Hydrol. Process., 16, 2751-2766, 2002.

Köhler, L., Mulligan, M., Schellekens, J., Schmid, S., and Tobón, C.: Hydrological impacts of converting tropical montane cloud forest to pasture, with initial reference to northern Costa Rica, Final Technical Report DFID-FRP Project no. R7991, 2006.

Marcotullio, P. J. and Onishi, T.: The impact of urbanization on soils, in: Land Use and Soil Resources, Springer, 201-250, 2008

Metzger, M., Rounsevell, M., Acosta-Michlik, L., Leemans, R., and Schröter, D.: The vulnerability of ecosystem services to land use change, Agr. Ecosyst. Environ., 114, 69-85, 2006.

Mundia, C. and Aniya, M.: Dynamics of landuse/cover changes and degradation of Nairobi City, Kenya, Land Degrad. Dev., 17, 97 108, 2006. 
Nash, J. E. and Sutcliffe, J. V.: River flow forecasting through conceptual models part I - a discussion of principles, J. Hydrol., 10, 282-290, 1970.

Poff, N. L., Allan, J. D., Bain, M. B., Karr, J. R., Prestegaard, K. L., Richter, B. D., Sparks, R. E., and Stromberg, J. C.: The natural flow regime, Bioscience, 47, 769-784, 1997.

Polasky, S., Nelson, E., Pennington, D., and Johnson, K.: The impact of land-use change on ecosystem services, biodiversity and returns to landowners: a case study in the state of Minnesota, Environ. Resour. Econ., 48, 219-242, https://doi.org/10.1007/s10640-010-9407-0, 2011.

Pradhan, B. and Suleiman, Z.: Landcover mapping and spectral analysis using multi-sensor satellite data fusion techniques: case study in Tioman Island, Malaysia, J. Geomat., 3, 71-78, 2009.

Richards, J., Xiuping, J., Gessner, W., and Ricken, D.: Remote sensing digital image analysis, 4th Edition, Springer, Berlin, Heidelberg, 25194-25199, 2006.

Richter, B. D., Baumgartner, J. V., Powell, J., and Braun, D. P.: A method for assessing hydrologic alteration within ecosystems, Conserv. Biol., 10, 1163-1174, 1996.

Rientjes, T. H. M., Haile, A. T., Kebede, E., Mannaerts, C. M. M., Habib, E., and Steenhuis, T. S.: Changes in land cover, rainfall and stream flow in Upper Gilgel Abbay catchment, Blue Nile basin - Ethiopia, Hydrol. Earth Syst. Sci., 15, 1979-1989, https://doi.org/10.5194/hess-15-1979-2011, 2011.

Schellekens, J.: WFlow, a flexible hydrological model, available at: https://publicwiki.deltares.nl/download/attachments/33226762/ wflow.pdf?version=1, 2011.

Teferi, E., Bewket, W., Uhlenbrook, S., and Wenninger, J.: Understanding recent land use and land cover dynamics in the source region of the Upper Blue Nile, Ethiopia: spatially explicit statistical modeling of systematic transitions, Agr. Ecosyst. Environ., 165, 98-117, https://doi.org/10.1016/j.agee.2012.11.007, 2013.
The Nature Conservancy.: Indicators of Hydrologic Alteration Version 7.1 User's Manual, The Nature Conservancy, Virginia, United States, 2009.

Turner, B. L., Matson, P. A., McCarthy, J. J., Corell, R. W., Christensen, L., Eckley, N., Hovelsrud-Broda, G. K., Kasperson, J. X., Kasperson, R. E., and Luers, A.: Illustrating the coupled humanenvironment system for vulnerability analysis: three case studies, P. Natl. Acad. Sci. USA, 100, 8080-8085, 2003.

Turner, B. L., Lambin, E. F., and Reenberg, A.: The emergence of land change science for global environmental change and sustainability, P. Natl. Acad. Sci. USA, 104, 20666-20671, 2007.

Uhlenbrook, S.: Biofuel and water cycle dynamics: what are the related challenges for hydrological processes research?, Hydrol. Process., 21, 3647-3650, 2007.

Uhlenbrook, S., Roser, S., and Tilch, N.: Hydrological process representation at the meso-scale: the potential of a distributed, conceptual catchment model, J. Hydrol., 291, 278-296, 2004.

Vertessy, R. A. and Elsenbeer, H.: Distributed modeling of storm flow generation in an Amazonian rain forest catchment: effects of model parameterization, Water Resour. Res., 35, 2173-2187, 1999.

Yuan, F., Bauer, M. E., Heinert, N. J., and Holden, G. R.: Multi-level land cover mapping of the Twin Cities (Minnesota) metropolitan area with multi-seasonal Landsat TM/ETM+ data, Geocarto. Int., 20, 5-13, 2005.

Zeleke, G. and Hurni, H.: Implications of land use and land cover dynamics for mountain resource degradation in the northwestern Ethiopian highlands, Mt. Res. Dev., 21, 184-191, 2001. 